\title{
Contribution to the Geological, Geochemical and Mineralogical Studies of Gabal Serbal Granitic Rocks, Southwestern Sinai, Egypt
}

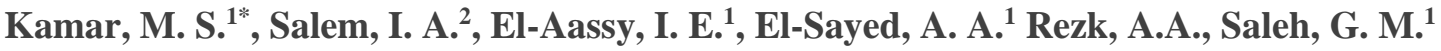 \\ ${ }^{1}$ Nuclear Materials Authority, P.O. Box 530, Cairo, Egypt, \\ ${ }^{2}$ Tanta University, Tanta, Egypt.
}

*Corresponding Author: Kamar, M. S., Nuclear Materials Authority, P.O. Box 530, Cairo, Egypt,

\begin{abstract}
Gabal Serbal area is located between latitudes $28^{\circ} 32^{\prime}-28^{\circ} 40^{\prime} 43^{\prime \prime} \mathrm{N}$ and longitudes $33^{\circ} 34^{\prime}-33^{\circ} 41^{\prime}$ $30^{\prime \prime} \mathrm{E}$ and includes the following rock varieties starting from the oldest: 1-Gneisses and migmatites, 2Metasediments-metavolcanics association, 3-Metagabbros, 4-Older granites, 5-Dokhan volcanics, 6-Younger granites and 7-Post granite dykes. Syenogranite and alkali feldspar granite have calc-alkaline to alkaline suite, emplaced in extensional environments during post orogenic regime and crystallized under low to moderate watervapour pressure $(1-5 \mathrm{~Kb})$ and temperature around $\left(800^{\circ} \mathrm{C}\right)$. The alkaline granite has peralkaline characters, emplaced in extensional environments during anorogenic regime. The radioactive anomalies are confined to fracture cuts of syenogranite at Wadis Geba and Abura. The average eU, eTh contents are (170, 82), (45, 80) ppm at Wadis Geba and Abura respectively. This high radioactivity due the presence of uranophane, uranothorite, samarskite, columbite, allanite, zircon, bastnäsite, xenotime, monazite, fluorite and wulfenite minerals..
\end{abstract}

Keywords: Gabal Serbal, Syenogranite, Geochemistry, Mineralization, Sinai, Egypt.

\section{INTRODUCTION}

The area is located between latitudes $28^{\circ} 32^{\prime}-28^{\circ} 40^{\prime} 43^{\prime \prime} \mathrm{N}$ and longitudes $33^{\circ} 34^{\prime}-33^{\circ} 41^{\prime} 30^{\prime \prime} \mathrm{E}$ (Figs. 1a and b). El-Shazly et al. (1974) and Shimron (1980) concluded that gneisses and migmatites are the oldest rock unit in Sinai reaching more than 1100 Ma. Feiran gneisses and migmatites were studied by many authors, some of them are Akaad et al., (1967), El-Gaby and Ahmed (1980), Bielski (1982), Shimron (1988) and Kusky and El-Shafei (1999). These rocks are highly deformed and display more than one generation of folds so they belong to Archean terranes (Twiss and Moores, 1992). El-Ramly (1972) considered Dokhan volcanics as younger than older granites, and older than the Hammamat sediments. Dokhan volcanics constitute a thick sequence of stratified lava flows of intermediate to acid composition together with subordinate sheets of ignimbrite and few intercalations of pyroclastics and formed by fractional crystallization of the basaltic magma generated by the partial melting of the upper mantle under relatively high oxygen fugacity (Basta et al., 1980). El-Gaby et al. (1988) suggested that the Dokhan volcanics and Hammamat sediments are penecontemporaneous and the Dokhan volcanics represent the surface manifestation of the syn- to late- tectonic calc-alkaline granite series.

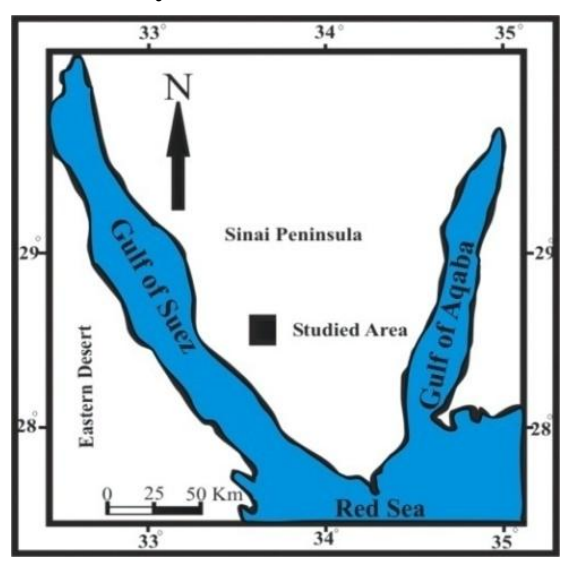

Fig.1a. Location map of the studied area 
Contribution to the Geological, Geochemical and Mineralogical Studies of Gabal Serbal Granitic Rocks, southwestern Sinai, Egypt

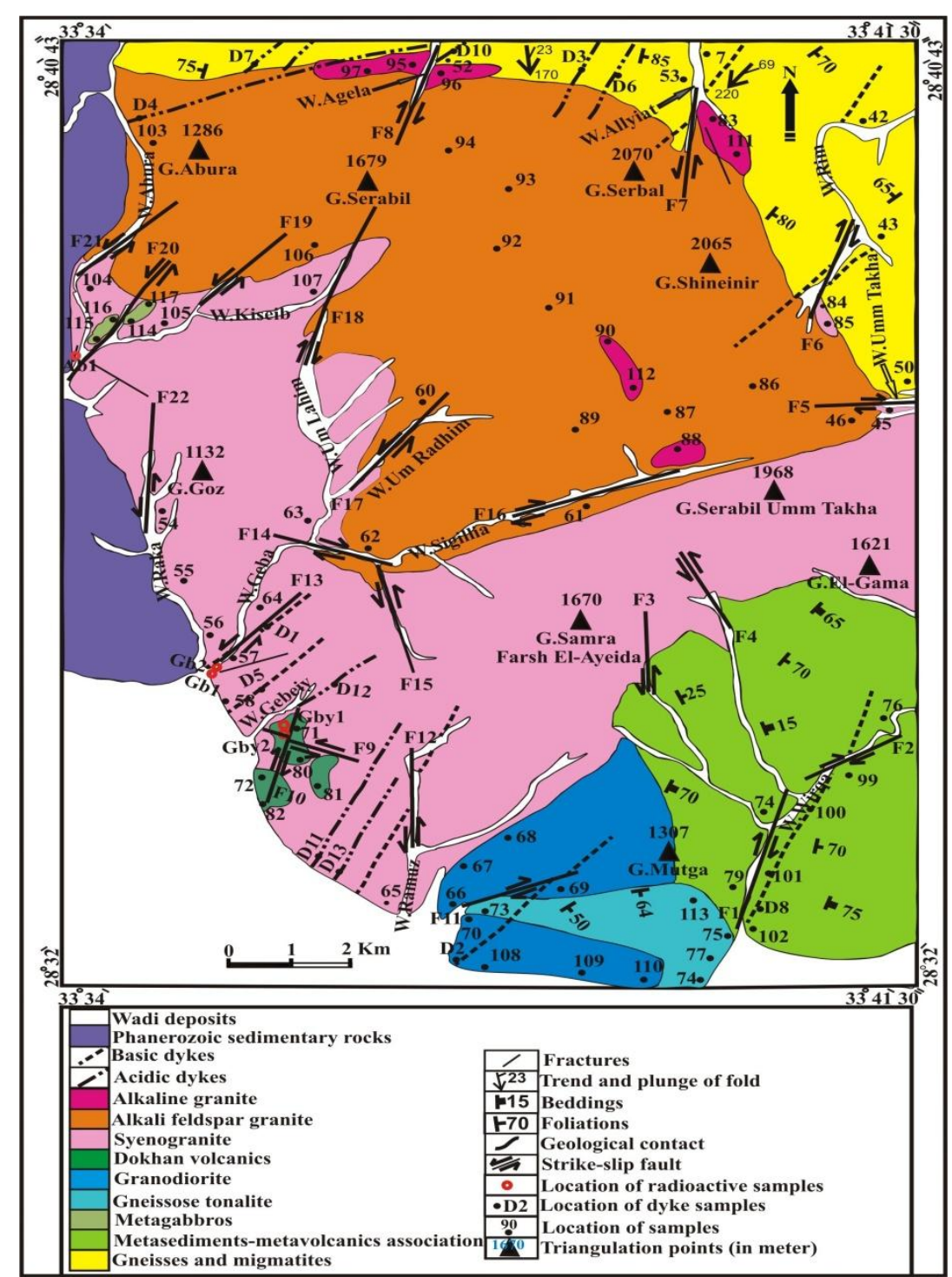

Fig. 1b. Geological map of G. Serbal area, southwestern Sinai, Egypt (after Kamar, 2011).

The present paper is one of the little studies that threw lights on the geology, geochemistry and mineralization restricted to the fresh and altered parts of granitic rocks of Gabal Serbal area.

\section{GEOLOGICAL SETTING}

The study area is covered by gneisses and migmatites, metasediments-metavolcanics association, metagabbros, older granites, Dokhan volcanics, younger granite, post granite dykes and phanerozoic sedimentary rocks (Fig. 1b). Gneisses and migmatites cover about $23 \mathrm{~km}^{2}$ and croup out at the northern and northeastern part of the mapped area. They are exposed at Wadi Agela, Wadi Allyiat (southern side of Wadi Feiran), Wadi Umm-Takha and Wadi Rim (southern side of Wadi Solaf). These gneisses are represented by hornblende biotite gneiss and biotite gneiss. They are medium- to coarse-grained with greyish green colour and show gneissose structure (Fig. 2). It forms moderate relief mountains and suffers intensive jointing of different directions producing easily weathered surfaces. The rocks are highly dissected by dykes of acidic and basic compositions. The migmatites comprise leucosome and melanosome bands (Fig. 3). They are mostly concordant; the contact between them is sharp. Metasediments-metavolcaics association is exposed at Wadi Wirqa and covers about $32 \mathrm{~km}^{2}$. It comprises hornblende schist and biotite schist intercalated with subordinate meta-andesite. The bedding planes and foliations are developed having nearly the same attitudes (Fig. 4). The rocks are highly weathered, jointed, dissected by strike-slip faults and cut by acidic and basic dykes. Metagabbros cover about $0.3 \mathrm{~km}^{2}$ and occur as xenoliths or as roof pendants uplifted by the syenogranites at Wadi Kiseib. The rocks are dark green and greyish green in colour, medium- to coarse-grained, low to moderate relief dissected by strike slip fault with sharp contact with syenogranite. They suffered hybridization, deuteric alteration and 
regional metamorphism, but they still retain their original igneous structure. Older granites are exposed between Wadi Ramuz and Wadi Wirqa and are represented by gneissose tonalite and granodiorite. Gneissose tonalite is hard massive grey colour, medium- to coarse-grained and forming moderate to high topographic relief. The gneissose tonalite is foliated (Fig. 5), cavernous, exfoliation and block weathering. The rock is invaded by acidic and basic dykes. The granodiorite is a hard massive rock of dark greenish grey colour and medium- to coarse-grained. The granodiorite rock is cavernous, exfoliated, weathered, jointed, faulted and dissected by acidic and basic dykes. Abundant enclaves are encountered especially close to the contact with metasediments-metavolcanics association. The Dokhan volcanics cover about 1.3 $\mathrm{km}^{2}$. They are represented by porphyritic dacite. The rocks are torn up due to intrusion of syenogranites. The rocks are grey to pinkish grey in colour, jointed, crushed, faulted and dissected by sinistral and dextral slip faults. Radioactive anomalies are recorded along the NNE-SSW fault plane and at the intersection with NW-SE trend. The syenogranite cover a considerable area $\left(73 \mathrm{~km}^{2}\right)$ and exposed at Wadis: Geba, Abura, Um Lahim, part of Um Radhim, Kiseib, part of Sigillia and Gabals Samra, Goz, Serabil Umm Takha and El-Gama. It is medium- to coarse -grained with pink colour forming medium to high relief mountain terrains. It attains cavernous weathering, ex-foliation, highly jointed and fractured (Fig. 6). Many of these joints are filled by copper mineralizations and/or pegmatite veins and bodies. Some fractures exhibit high alteration products represented by hematization, desilicification and record high radioactivity (Wadis; Geba and Abura). Microscopically, it is composed essentially of K-feldspar (55.78 in vol. \%), quartz (26.19 in vol. \%), plagioclase (15.25 in vol. \%), biotite (2.22 in vol. \%). Muscovite (0.25 in vol. \%), zircon, allanite, apatite, sphene and opaques $(0.31$ in vol. \%) are accessories. Alkali feldspar granite exposed at Wadis: Abura, Um Radhim, Sigillia and ends of Wadis; Agela, Allyiat and Rim and Gabals; Abura, Serbal, Serabil and Shineinir. It covers an area $\left(86 \mathrm{~km}^{2}\right)$ and is devoid of xenoliths. It is medium- to coarsegrained with red colour forming high relief mountain terrains (Fig. 7). The rocks are jointed, devoid of xenoliths and form gradational contact with syenogranite (Fig. 8). Microscopically, it is composed essentially of K-feldspar (65.69 in vol. \%), quartz (28.47 in vol. \%), plagioclase (4.47 in vol. \%), biotite $(0.79$ in vol. \%) and rarely muscovite (0.05 in vol. \%). Zircon, allanite and opaques ( 0.53 in vol. \%) are accessories. The alkaline granite covers an area $\left(2.50 \mathrm{~km}^{2}\right)$ and is exposed at the ends of Wadis: Agela, Allyiat and Gabals Serbal and Shineinir. It is medium- to coarse-grained with pinkish white colour forming small intrusion rounded or oval in plan. Sometimes occurs with or as offshoots in alkali feldspar granites with sharp contacts (Fig. 9). Microscopically, it is composed essentially of K-feldspar (67.85 in vol. \%), quartz (27.49 in vol. \%), alkaline minerals (3.85 in vol. \%), rarely plagioclase (0.18 in vol. \%) and biotite $(0.09$ in vol. \%). Zircon, allanite and opaques (0.54 in vol. \%) are accessories.

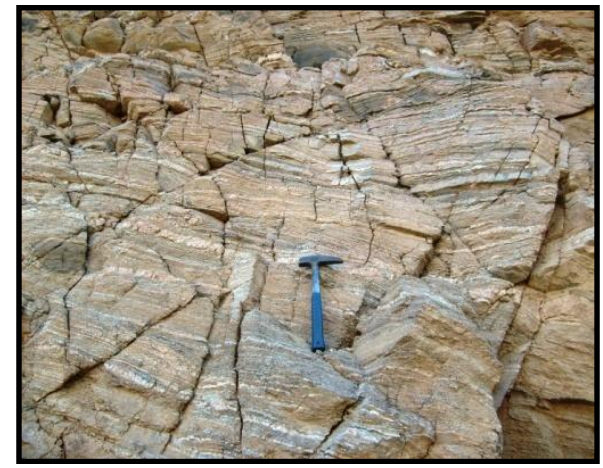

Fig. 2. Gneissose structure in gneisses and migmatites at Wadi Agela, Looking $N 40^{\circ} \mathrm{E}$

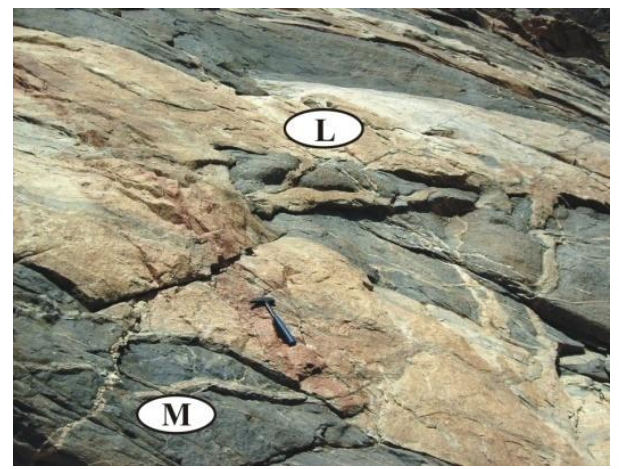

Fig. 3. Leucosomes (L) and melanosomes (M) in migmatites at Wadi Agela, Looking $N 35^{\circ} \mathrm{E}$ 
Contribution to the Geological, Geochemical and Mineralogical Studies of Gabal Serbal Granitic Rocks, southwestern Sinai, Egypt

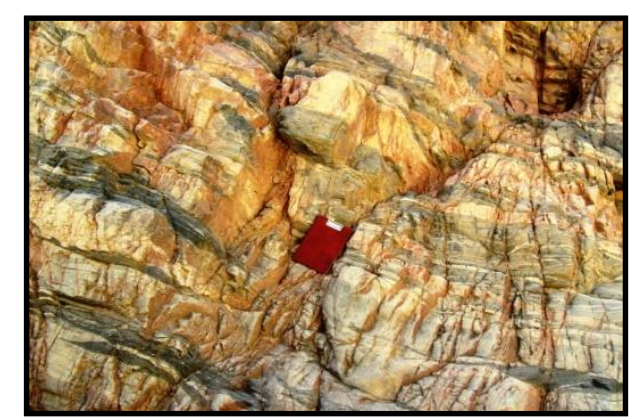

Fig. 4. Bedding planes and foliations (schistosity) in metasediments-metavolcanics association at Wadi Wirqa. Looking $S 70^{\circ} \mathrm{E}$

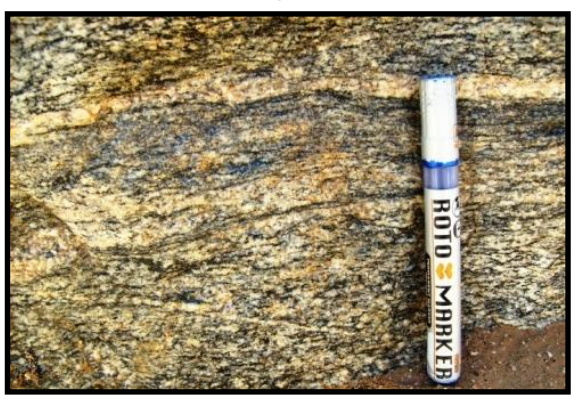

Fig. 5. Gneissose texture in gneissose tonalite near Wadi Wirqa, Looking E.

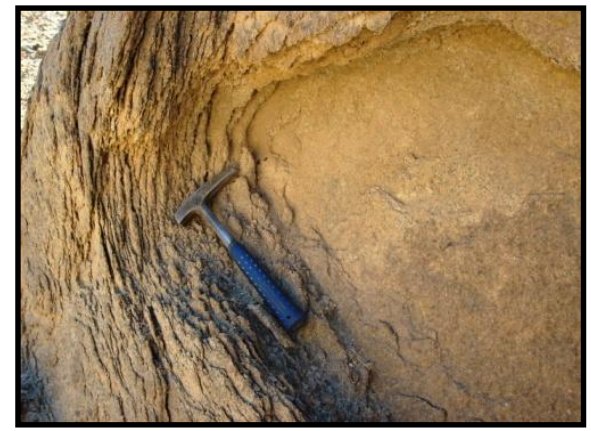

Fig. 6. Cavernous and ex-foliation in syenogranite at Wadi Geba, Looking $S 50^{\circ} E$

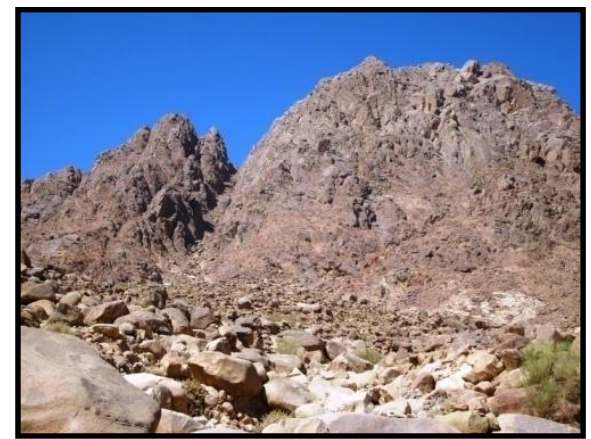

Fig. 7. High mountain terrain of alkali feldspar granite at G. Serabil, Looking $S 50^{\circ} \mathrm{W}$

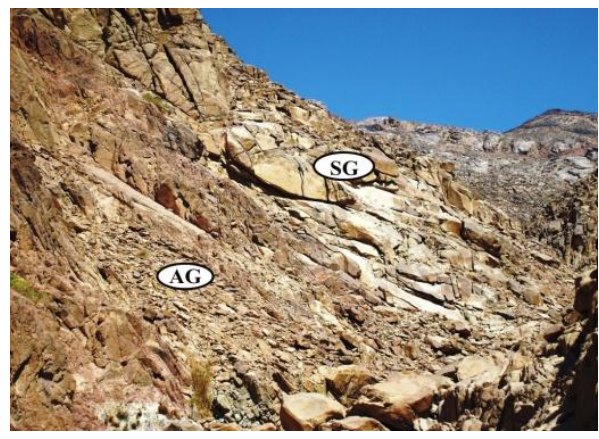

Fig. 8. Gradational contact between syenogranite $(S G)$ and alkali feldspar granite $(A G)$ at Wadi Kiseib, Looking $S 50^{\circ} \mathrm{E}$ 


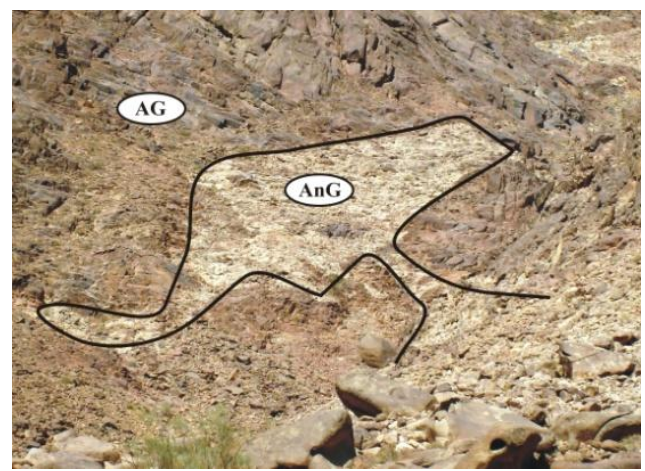

Fig. 9. Offshoots from alkaline granite $(A n G)$ in alkali feldspar granite $(A G)$ at $G$. Serabil, Looking $S 75^{\circ} W$

The area is dissected by conspicuous clusters of post granite dykes forming distinct, fairly long subparallel dyke swarms. Field measurements indicate that these dykes are oriented to the NE-SW and less significantly to ENE-WSW, NNE-SSW, N-S and E-W.

\section{Methods of StUdy}

Thirty five (35) chemical analyses (11 for fresh and 3 for altered syenogranites, 13 for alkali feldspar granites and 8 for alkaline granites) were chemically analyzed. Major oxides were performed by wet chemistry methods, where trace elements were analyzed by X-ray fluorescence. Uranium and thorium were chemically analyzed for the same samples by spectrophotometry (Marchzenko, 1986). The concentration of equivalent uranium (eU) in ppm, equivalent thorium (eTh) in ppm, radium (Ra) in $\mathrm{ppm}$ and potassium $(\mathrm{K})$ in \% were determined using multi-channel analyzer (Gamma spectrometric technique) using a Bicron Scintillation Detector $\mathrm{NaI}(\mathrm{Tl}) 76$ x $76 \mathrm{~mm}$. All analyses were measured in the Laboratories of Nuclear Materials Authority. The heavy minerals were separated using heavy liquid (bromoform) separation technique, followed by magnetic fractionation using Frantz isodynamic separator. The heavy minerals were picked by the binocular microscope and identified by X-ray diffraction and Scanning Electron Microscope (SEM)-Energy Dispersive X-ray (EDX) techniques.

\section{RESUlT AND DISCUSSION}

\subsection{Geochemistry}

\subsubsection{Geochemistry of fresh granites}

The results of thirty two (32) chemical analyses (11 for syenogranites, 13 for alkali feldspar granites and 8 for alkaline granites) and CIPW normative values are given in Tables (1 to 6).

Table1. Major oxides (wt\%) and CIPW normative of syenogranite of G. Serbal area, SW Sinai, Egypt

\begin{tabular}{|c|c|c|c|c|c|c|c|c|c|c|c|}
\hline Oxides & 45 & 54 & 55 & 63 & 64 & 65 & 85 & 104 & 105 & 107 & $\mathbf{A B}$ \\
\hline $\mathrm{SiO}_{2}$ & 72.35 & 72.23 & 72.75 & 72.85 & 73.52 & 73.53 & 73.21 & 73.40 & 74.41 & 72.65 & 73.60 \\
\hline $\mathrm{TiO}_{2}$ & 0.22 & 0.27 & 0.27 & 0.25 & 0.23 & 0.26 & 0.25 & 0.20 & 0.25 & 0.24 & 0.20 \\
\hline $\mathrm{Al}_{2} \mathrm{O}_{3}$ & 13.10 & 13.26 & 13.71 & 13.97 & 13.30 & 13.95 & 13.12 & 13.29 & 12.82 & 13.18 & 12.90 \\
\hline $\mathrm{Fe}_{2} \mathrm{O}_{3}$ & 2.22 & 2.07 & 1.73 & 1.64 & 1.53 & 2.0 & 2.09 & 1.40 & 1.35 & 1.70 & 2.10 \\
\hline FeO & 0.48 & 0.72 & 0.77 & 0.56 & 0.57 & 0.19 & 0.40 & 0.80 & 0.65 & 0.70 & 0.80 \\
\hline MgO & 0.90 & 1.0 & 1.0 & 0.90 & 0.85 & 0.90 & 0.90 & 0.90 & 0.90 & 0.90 & 1.0 \\
\hline $\mathrm{CaO}$ & 1.40 & 1.20 & 1.40 & 1.30 & 1.20 & 1.0 & 1.0 & 1.10 & 0.90 & 1.0 & 1.10 \\
\hline $\mathrm{Na}_{2} \mathrm{O}$ & 3.99 & 3.58 & 3.20 & 2.98 & 3.58 & 3.90 & 3.67 & 3.59 & 3.78 & 3.99 & 3.90 \\
\hline $\mathrm{K}_{2} \mathrm{O}$ & 4.06 & 4.31 & 3.87 & 3.85 & 4.30 & 4.06 & 4.16 & 3.96 & 4.30 & 3.74 & 3.60 \\
\hline $\mathbf{P}_{2} \mathrm{O}_{5}$ & 0.22 & 0.15 & 0.20 & 0.23 & 0.23 & 0.23 & 0.17 & 0.16 & 0.15 & 0.18 & 0.16 \\
\hline L.O.I & 0.59 & 0.69 & 0.75 & 0.94 & 0.72 & 0.84 & 0.96 & 0.60 & 0.71 & 0.66 & 0.65 \\
\hline Total & 99.53 & 99.48 & 99.65 & 99.47 & 100.03 & 100.86 & 99.93 & 99.40 & 100.22 & 98.94 & 100.01 \\
\hline \multicolumn{12}{|c|}{ CIPW normative values } \\
\hline $\mathbf{Q z}$ & 30.16 & 31.63 & 35.75 & 37.81 & 33.23 & 32.42 & 33.25 & 34.50 & 33.26 & 32.68 & 33.93 \\
\hline Or & 24.17 & 25.81 & 23.15 & 23.11 & 25.61 & 24.01 & 24.86 & 23.71 & 25.56 & 22.51 & 21.43 \\
\hline $\mathbf{A b}$ & 34.08 & 30.63 & 27.35 & 25.56 & 30.47 & 32.95 & 31.34 & 30.71 & 32.10 & 34.31 & 33.17 \\
\hline An & 5.72 & 5.14 & 5.84 & 5.18 & 4.64 & 3.61 & 4.01 & 4.58 & 3.60 & 3.98 & 4.55 \\
\hline $\mathbf{C}$ & 0.05 & 0.84 & 2.15 & 3.06 & 1.06 & 1.80 & 1.12 & 1.45 & 0.62 & 1.14 & 0.92 \\
\hline Hy(en) & 2.27 & 2.53 & 2.53 & 2.28 & 2.14 & 2.25 & 2.27 & 2.28 & 2.26 & 2.29 & 2.52 \\
\hline
\end{tabular}


Contribution to the Geological, Geochemical and Mineralogical Studies of Gabal Serbal Granitic Rocks, southwestern Sinai, Egypt

\begin{tabular}{|l|l|l|l|l|l|l|l|l|l|l|l|}
\hline Mt & 0.92 & 1.56 & 1.72 & 1.10 & 1.18 & 0.61 & 0.57 & 2.02 & 1.38 & 1.59 & 2.01 \\
\hline He & 1.61 & 1.02 & 0.57 & 0.91 & 0.73 & 1.58 & 1.72 & 0.02 & 0.41 & 0.64 & 0.73 \\
\hline Il & 0.42 & 0.52 & 0.52 & 0.48 & 0.44 & 0 & 0.4 & 0.38 & 0.48 & 0.46 & 0.38 \\
\hline Ap & 0.49 & 0.33 & 0.44 & 0.51 & 0.51 & 0.50 & 0.37 & 0.35 & 0.33 & 0.40 & 0.35 \\
\hline
\end{tabular}

Table2. Trace elements concentration (ppm) of syenogranites of G. Serbal area, SW Sinai, Egypt

\begin{tabular}{|c|c|c|c|c|c|c|c|c|c|c|c|}
\hline \begin{tabular}{l|} 
Trace \\
Elements \\
\end{tabular} & 45 & 54 & 55 & 63 & 64 & 65 & 85 & 104 & 105 & 107 & $\mathrm{AB}$ \\
\hline $\mathrm{Cr}$ & 17 & 21 & 24 & 18 & 21 & 19 & 20 & 17 & 16 & 18 & 18 \\
\hline $\mathbf{N i}$ & 10 & 11 & 10 & 11 & 14 & 12 & 10 & 11 & 12 & 11 & 12 \\
\hline $\mathbf{C u}$ & 11 & 9 & 11 & 10 & 10 & 11 & 11 & 10 & 10 & 10 & 10 \\
\hline $\mathbf{Z n}$ & 65 & 101 & 81 & 84 & 52 & 44 & 35 & 63 & 74 & 66 & 69 \\
\hline $\mathbf{Z r}$ & 230 & 488 & 313 & 335 & 331 & 409 & 340 & 650 & 466 & 650 & 552 \\
\hline $\mathbf{R b}$ & 118 & 105 & 120 & 102 & 118 & 130 & 115 & 135 & 137 & 127 & 129 \\
\hline $\mathbf{Y}$ & 36 & 67 & 65 & 45 & 51 & 63 & 65 & 55 & 54 & 49 & 54 \\
\hline $\mathbf{B a}$ & 355 & 360 & 350 & 360 & 295 & 290 & 290 & 338 & 317 & 344 & 302 \\
\hline $\mathbf{P b}$ & 20 & 15 & 15 & 12 & 15 & 17 & 26 & 10 & 11 & 13 & 11 \\
\hline $\mathbf{S r}$ & 98 & 100 & 90 & 98 & 91 & 65 & 85 & 80 & 56 & 88 & 62 \\
\hline Ga & 21 & 21 & 22 & 20 & 20 & 22 & 17 & 19 & 21 & 20 & 20 \\
\hline $\mathbf{V}$ & 6 & 12 & 10 & 14 & 8 & 3 & 3 & 11 & 13 & 9 & 12 \\
\hline $\mathrm{Nb}$ & 12 & 20 & 21 & 15 & 8 & 16 & 9 & 10 & 21 & 16 & 12 \\
\hline $\mathbf{U}$ & 12 & 11 & 10 & 8 & 10 & 18 & 12 & 11 & 17 & 21 & 15 \\
\hline Th & 21 & 20 & 22 & 13 & 16 & 26 & 30 & 21 & 23 & 32 & 26 \\
\hline \multicolumn{12}{|c|}{ Geochemical Parameters } \\
\hline $\mathbf{K} / \mathbf{R b}$ & 285.6 & 340.75 & 267.72 & 313.33 & 302.51 & 259.26 & 300.29 & 243.5 & 260.55 & 244.46 & 231.66 \\
\hline $\mathbf{B a} / \mathbf{R b}$ & 3.01 & 3.43 & 2.92 & 3.53 & 2.50 & 2.23 & 2.52 & 2.50 & 2.31 & 2.71 & 2.34 \\
\hline $\mathbf{R b} / \mathbf{S r}$ & 1.2 & 1.05 & 1.33 & 1.04 & 1.30 & 2.0 & 1.35 & 1.69 & 2.45 & 1.44 & 2.08 \\
\hline $\mathbf{Z r} / \mathbf{S r}$ & 2.35 & 4.88 & 3.48 & 3.42 & 3.64 & 6.29 & 4.0 & 8.13 & 8.32 & 7.39 & 8.90 \\
\hline $\mathbf{Y} / \mathbf{N b}$ & 3.0 & 3.35 & 3.10 & 3.0 & 3.10 & 3.94 & 7.22 & 5.50 & 2.57 & 3.06 & 4.50 \\
\hline
\end{tabular}

Table3. Major oxides (wt\%) and CIPW normative of alkali feldspar granite of G. Serbal area, SW Sinai, Egypt

\begin{tabular}{|c|c|c|c|c|c|c|c|c|c|c|c|c|c|}
\hline & 46 & 60 & 61 & 62 & 86 & 87 & 89 & 91 & \begin{tabular}{|l|}
92 \\
\end{tabular} & \begin{tabular}{|r|}
93 \\
\end{tabular} & 94 & 103 & 106 \\
\hline $\mathrm{SiO}_{2}$ & 74.43 & 3.68 & 73.30 & 3.91 & 74.11 & 73.15 & 73.16 & 73.90 & 73.88 & 74.88 & 74.55 & & 74.30 \\
\hline $\mathrm{O}_{2}$ & 0.16 & 19 & 18 & 17 & 0.16 & 14 & 0.17 & 17 & 0.18 & 0.19 & 0.16 & & \\
\hline${ }_{2} \mathrm{O}_{3}$ & 12.72 & .70 & 2.90 & & 2.60 & .70 & 2.64 & 2.80 & 12.92 & 2.24 & & & 2.77 \\
\hline${ }_{22} \mathrm{O}_{3}$ & 1.37 & 1.29 & 1.39 & 1.10 & 1.16 & 18 & 1.14 & 1.39 & 1.01 & 1.29 & 1.30 & 1.38 & 1.09 \\
\hline & 0.02 & & 0.40 & & & & & .40 & & .21 & & & .31 \\
\hline & 0.60 & & & 0.7 & & & & 60 & & .50 & 0.70 & .70 & 60 \\
\hline & & & & & & & & & & & & & \\
\hline & & 4. & & & & & & .1 & 4.21 & .15 & 4.0 & & \\
\hline & 4.69 & 4.60 & 4.42 & 4.86 & $4.5 \mathrm{C}$ & 4.99 & 4.86 & 4.46 & 4.78 & 1.82 & 4.89 & 1.80 & 4.99 \\
\hline & & 0.14 & & 0.11 & 0.1 & 0.13 & 0.12 & 0.09 & 0.12 & 0.11 & 0.01 & 0.09 & .12 \\
\hline & 0.94 & 0.80 & 1.24 & 0.94 & 0.94 & 0.95 & 1.64 & 0.99 & 0.71 & 0.95 & 0.73 & 0.90 & 0.81 \\
\hline & 99.82 & 99.89 & 99.86 & 99.26 & 99.30 & 99.66 & 99.50 & 99.80 & 99.48 & 100.14 & 99.56 & 99.20 & 100.0 \\
\hline \multicolumn{14}{|c|}{ CIPW Normative Values } \\
\hline $\mathbf{z}$ & 31.58 & 27.73 & 29.02 & 29.69 & 30.89 & 28.96 & 29.04 & 30.92 & 29.35 & 31.0 & 30.84 & 27.42 & 29.97 \\
\hline & 28.06 & 27.46 & 65.51 & 29.33 & 27.60 & 29.90 & 29.38 & 26.70 & 28.63 & 28.74 & 29.27 & 28.88 & 29.73 \\
\hline Ab & 33.85 & 39.15 & 37.71 & 35.76 & 35.74 & 35.96 & 35.58 & 35.07 & 35.94 & 35.36 & 34.38 & 36.63 & 34.14 \\
\hline & 3.08 & 0.43 & 2.39 & 0.87 & 2.15 & 1.04 & 1.64 & 3.35 & 2.27 & 0.50 & 0.55 & 2.03 & 2.08 \\
\hline & 0.07 & 1.35 & 0.57 & 1.05 & 0.65 & 0.92 & 0.92 & 0.26 & 0.64 & 1.19 & 1.41 & 1.03 & 0.71 \\
\hline & 06 & 1.17 & 0.49 & 0.90 & 0.56 & 0.80 & \begin{tabular}{|l|l|}
0.79 \\
\end{tabular} & 0.23 & 0.55 & 1.05 & 1.21 & 0.89 & \begin{tabular}{|l|}
0.61 \\
\end{tabular} \\
\hline & & 0.60 & 1.03 & 0.87 & 0.71 & 0.47 & 0.99 & 1.29 & 0.97 & 0.23 & 0.56 & 0.89 & 0.90 \\
\hline & 0.07 & 0.42 & 0.78 & 0.29 & 0.1 & 0.63 & 0.16 & 0.81 & 0.06 & 0.13 & 0.29 & 0.75 & 0.48 \\
\hline He & 1.34 & 1.01 & 0.87 & 0.92 & 1.09 & 0.76 & 1.05 & 0.85 & 0.98 & 1.21 & 1.11 & 0.88 & 0.77 \\
\hline II & & 0.36 & 0.35 & 0 & & 0.27 & 0 & 0.33 & 0.35 & 0.36 & & 0.39 & 0.34 \\
\hline ap & & 0.31 & 0.29 & 0.24 & 0.31 & 0.29 & 0.27 & 0.20 & 0.27 & 0.24 & 0.22 & 0.20 & 0.26 \\
\hline
\end{tabular}


Contribution to the Geological, Geochemical and Mineralogical Studies of Gabal Serbal Granitic Rocks, southwestern Sinai, Egypt

Table4. Trace elements concentration (ppm) of alkali feldspar granites of G. Serbal area, SW Sinai, Egypt.

\begin{tabular}{|l|l|l|l|l|l|l|l|l|l|l|l|l|l|}
\hline $\begin{array}{c}\text { Trace } \\
\text { Elements }\end{array}$ & $\mathbf{4 6}$ & $\mathbf{6 0}$ & $\mathbf{6 1}$ & $\mathbf{6 2}$ & $\mathbf{8 6}$ & $\mathbf{8 7}$ & $\mathbf{8 9}$ & $\mathbf{9 1}$ & $\mathbf{9 2}$ & $\mathbf{9 3}$ & $\mathbf{9 4}$ & $\mathbf{1 0 3}$ & $\mathbf{1 0 6}$ \\
\hline $\mathbf{C r}$ & 14 & 13 & 15 & 15 & 13 & 13 & 13 & 13 & 14 & 13 & 14 & 13 & 15 \\
\hline $\mathbf{N i}$ & 7 & 6 & 9 & 6 & 7 & 7 & 7 & 10 & 9 & 8 & 9 & 8 & 8 \\
\hline $\mathbf{C u}$ & 11 & 9 & 12 & 12 & 10 & 10 & 9 & 18 & 10 & 11 & 15 & 9 & 10 \\
\hline $\mathbf{Z n}$ & 101 & 83 & 55 & 63 & 69 & 72 & 88 & 64 & 86 & 77 & 44 & 61 & 41 \\
\hline $\mathbf{Z r}$ & 680 & 1000 & 681 & 660 & 675 & 863 & 672 & 895 & 740 & 665 & 699 & 770 & 652 \\
\hline $\mathbf{R b}$ & 226 & 189 & 221 & 203 & 205 & 203 & 165 & 175 & 231 & 231 & 204 & 165 & 231 \\
\hline $\mathbf{Y}$ & 70 & 81 & 79 & 80 & 84 & 84 & 85 & 93 & 83 & 94 & 79 & 80 & 82 \\
\hline $\mathbf{B a}$ & 57 & 285 & 225 & 184 & 83 & 59 & 65 & 200 & 60 & 101 & 118 & 169 & 64 \\
\hline $\mathbf{P b}$ & 14 & 8 & 11 & 8 & 9 & 16 & 8 & 12 & 14 & 17 & 14 & 12 & 4 \\
\hline $\mathbf{S r}$ & 15 & 58 & 54 & 41 & 30 & 15 & 23 & 55 & 26 & 26 & 29 & 54 & 16 \\
\hline $\mathbf{G a}$ & 26 & 20 & 20 & 15 & 21 & 24 & 22 & 21 & 22 & 24 & 23 & 20 & 19 \\
\hline $\mathbf{V}$ & 2 & 8 & 8 & 6 & 3 & 2 & 3 & 7 & 3 & 4 & 3 & 7 & 2 \\
\hline $\mathbf{N b}$ & 33 & 23 & 28 & 27 & 25 & 22 & 23 & 33 & 31 & 29 & 25 & 26 & 27 \\
\hline $\mathbf{U}$ & 20 & 12 & 14 & 13 & 15 & 21 & 15 & 12 & 18 & 54 & 62 & 28 & 38 \\
\hline $\mathbf{T h}$ & 28 & 21 & 28 & 27 & 33 & 35 & 29 & 25 & 29 & 34 & 38 & 39 & 34 \\
\hline $\mathbf{9}$ & \multicolumn{9}{|c|}{$\mathbf{G e o c h e m i c a l ~ P a r a m e t e r s}$} & & & & \\
\hline $\mathbf{K} / \mathbf{R b}$ & 172.27 & 202.04 & 166.03 & 198.74 & 185.87 & 204.06 & 244.51 & 211.56 & 171.78 & 173.21 & 198.99 & 241.49 & 179.32 \\
\hline $\mathbf{B a} / \mathbf{R b}$ & 0.25 & 1.51 & 1.02 & 0.91 & 0.40 & 0.29 & 0.39 & 1.14 & 0.26 & 0.44 & 0.58 & 1.02 & 0.28 \\
\hline $\mathbf{R b} / \mathbf{S r}$ & 15.07 & 3.26 & 4.09 & 4.95 & 6.83 & 13.53 & 7.17 & 3.18 & 8.88 & 8.88 & 7.03 & 3.06 & 14.44 \\
\hline $\mathbf{Z r} / \mathbf{S r}$ & 45.33 & 17.24 & 12.61 & 16.10 & 22.50 & 57.53 & 29.22 & 16.27 & 28.46 & 25.58 & 24.10 & 14.26 & 40.75 \\
\hline $\mathbf{Y} / \mathbf{N b}$ & 2.12 & 3.52 & 2.82 & 2.96 & 3.36 & 3.82 & 3.70 & 2.82 & 2.68 & 3.24 & 3.16 & 3.08 & 3.04 \\
\hline
\end{tabular}

Table5. Major oxides (wt\%) and CIPW normative of alkaline granite of G. Serbal area, SW Sinai, Egypt.

\begin{tabular}{|c|c|c|c|c|c|c|c|c|}
\hline Oxides & 83 & 88 & 90 & 95 & 96 & 97 & 111 & 112 \\
\hline $\mathrm{SiO}_{2}$ & 73.88 & 74.70 & 74.63 & 73.90 & 75.53 & 74.9 & 75.2 & 75.60 \\
\hline $\mathrm{TiO}_{2}$ & 0.20 & 0.12 & 0.13 & 0.11 & 0.10 & 0.11 & 0.10 & 0.10 \\
\hline $\mathrm{Al}_{2} \mathrm{O}_{3}$ & 12.15 & 11.27 & 11.64 & 11.75 & 11.98 & 11.55 & 11.40 & 11.20 \\
\hline $\mathrm{Fe}_{2} \mathrm{O}_{3}$ & 2.60 & 1.80 & 2.29 & 1.60 & 1.67 & 2.05 & 1.75 & 1.59 \\
\hline $\mathrm{FeO}$ & 0.10 & 0.79 & 0.51 & 0.50 & 0.53 & 0.65 & 0.55 & 0.51 \\
\hline MgO & 0.10 & 0.20 & 0.15 & 0.10 & 0.09 & 0.15 & 0.10 & 0.08 \\
\hline $\mathrm{CaO}$ & 0.40 & 0.50 & 0.30 & 0.30 & 0.20 & 0.25 & 0.22 & 0.19 \\
\hline $\mathrm{Na}_{2} \mathrm{O}$ & 5.59 & 4.90 & 5.18 & 5.20 & 5.20 & 5.21 & 5.21 & 5.22 \\
\hline $\mathbf{K}_{2} \mathbf{O}$ & 4.37 & 4.62 & 4.40 & 4.80 & 4.52 & 4.45 & 4.50 & 4.55 \\
\hline $\mathbf{P}_{2} \mathbf{O}_{5}$ & 0.08 & 0.08 & 0.08 & 0.05 & 0.05 & 0.07 & 0.06 & 0.04 \\
\hline L.O.I & 0.87 & 0.84 & 0.74 & 0.79 & 0.47 & 0.61 & 0.75 & 0.75 \\
\hline Total & 100.34 & 99.82 & 100.05 & 99.10 & 100.34 & 100.0 & 99.84 & 99.83 \\
\hline \multicolumn{9}{|c|}{ CIPW Normative Values } \\
\hline $\mathbf{Q z}$ & 48.8 & 49.44 & 49.76 & 48.77 & 50.72 & 49.97 & 50.72 & 51.18 \\
\hline Or & 26.03 & 27.61 & 26.40 & 28.88 & 26.77 & 26.49 & 26.86 & 27.16 \\
\hline Ac & 7.27 & 5.25 & 6.66 & 4.70 & 4.83 & 5.96 & 5.10 & 4.63 \\
\hline Ns & 9.16 & 8.35 & 8.51 & 9.17 & 8.97 & 8.72 & 9.10 & 9.14 \\
\hline Di (wo) & 0.45 & 0.85 & 0.43 & 0.51 & 0.29 & 0.35 & 0.31 & 0.30 \\
\hline Di (en) & 0.25 & 0.25 & 0.15 & 0.14 & 0.07 & 0.10 & 0.08 & 0.07 \\
\hline Di (fs) & 0.18 & 0.63 & 0.29 & 0.40 & 0.24 & 0.27 & 0.25 & 0.25 \\
\hline Hy (en) & 0 & 0.25 & 0.23 & 0.12 & 0.16 & 0.28 & 0.18 & 0.14 \\
\hline Hy (fs) & 0 & 0.63 & 0.44 & 0.35 & 0.56 & 0.75 & 0.60 & 0.52 \\
\hline II & 0 & 0.23 & 0.25 & 0.21 & 0.19 & 0.21 & 0.19 & 0.19 \\
\hline Ap & 0.18 & 0.18 & 0.18 & 0.11 & 0.11 & 0.15 & 0.13 & 0.09 \\
\hline
\end{tabular}

Table6. Trace elements concentration (ppm) of alkaline granites of G. Serbal area, SW Sinai, Egypt.

\begin{tabular}{|c|c|c|c|c|c|c|c|c|}
\hline $\begin{array}{c}\text { Trace } \\
\text { Elements }\end{array}$ & $\mathbf{8 3}$ & $\mathbf{8 8}$ & $\mathbf{9 0}$ & $\mathbf{9 5}$ & $\mathbf{9 6}$ & $\mathbf{9 7}$ & $\mathbf{1 1 1}$ & $\mathbf{1 1 2}$ \\
\hline $\mathbf{C r}$ & 12 & 11 & 12 & 12 & 11 & 12 & 10 & 11 \\
\hline $\mathbf{N i}$ & 5 & 6 & 7 & 7 & 5 & 6 & 5 & 6 \\
\hline $\mathbf{C u}$ & 10 & 10 & 10 & 11 & 12 & 16 & 18 & 15 \\
\hline
\end{tabular}


Contribution to the Geological, Geochemical and Mineralogical Studies of Gabal Serbal Granitic Rocks, southwestern Sinai, Egypt

\begin{tabular}{|c|c|c|c|c|c|c|c|c|}
\hline $\mathbf{Z n}$ & 112 & 121 & 96 & 101 & 83 & 110 & 109 & 102 \\
\hline $\mathbf{Z r}$ & 720 & 822 & 763 & 700 & 810 & 660 & 670 & 881 \\
\hline $\mathbf{R b}$ & 237 & 235 & 306 & 245 & 294 & 236 & 235 & 240 \\
\hline $\mathbf{Y}$ & 98 & 117 & 108 & 98 & 104 & 99 & 94 & 98 \\
\hline $\mathbf{B a}$ & 50 & 55 & 27 & 40 & 35 & 58 & 55 & 53 \\
\hline $\mathbf{P b}$ & 17 & 15 & 18 & 13 & 12 & 17 & 16 & 16 \\
\hline $\mathbf{S r}$ & 7 & 9 & 9 & 10 & 8 & 7 & 6 & 6 \\
\hline $\mathbf{G a}$ & 23 & 25 & 24 & 21 & 24 & 22 & 23 & 25 \\
\hline $\mathbf{V}$ & 2 & 3 & 3 & 2 & 2 & 2 & 2 & 2 \\
\hline $\mathbf{N b}$ & 36 & 46 & 35 & 38 & 40 & 37 & 40 & 41 \\
\hline $\mathbf{U}$ & 14 & 18 & 22 & 17 & 25 & 16 & 20 & 21 \\
\hline $\mathbf{T h}$ & 29 & 31 & 38 & 30 & 35 & 31 & 34 & 32 \\
\hline \multicolumn{7}{|r|}{} & \multicolumn{7}{|c|}{$\mathbf{G e o c h e m i c a l ~ P a r a m e t e r s}$} & & & 157.38 \\
\hline $\mathbf{K} / \mathbf{R b}$ & 153.07 & 163.20 & 119.37 & 162.64 & 127.63 & 156.53 & 158.96 & 0.22 \\
\hline $\mathbf{B a} / \mathbf{R b}$ & 0.21 & 0.23 & 0.09 & 0.16 & 0.12 & 0.25 & 0.23 & 0.0 \\
\hline $\mathbf{R b} / \mathbf{S r}$ & 33.86 & 26.11 & 34.0 & 25.50 & 36.75 & 33.71 & 39.17 & 40.0 \\
\hline $\mathbf{Z r / S r}$ & 102.86 & 91.33 & 84.78 & 70.0 & 101.25 & 94.29 & 111.67 & 146.83 \\
\hline $\mathbf{Y} / \mathbf{N b}$ & 2.72 & 2.54 & 3.09 & 2.58 & 2.60 & 2.68 & 2.35 & 2.39 \\
\hline
\end{tabular}

On the basis of $R_{1}-R_{2}$ discrimination diagram of De La-Roche et al. (1980), the studied younger granites fall in syenogranite and alkali feldspar granite (Fig. 10). When applying the alumina saturation of Clarke (1981) on Shand's index diagram (Fig. 11) the studied syenogranite has peraluminous characters except one sample of syenogranite lying in a metaluminous field. The samples of alkali feldspar granite lie in a metaluminous field, while alkaline granite samples concentrate in the peralkaline field. According to Sylvester (1989), syenogranite samples lie in calcalkaline and alkaline fields. The alkali feldspar granite samples lie in the alkaline and highly fractionated calc-alkaline field, while alkaline granite lies in the alkaline field (Fig. 12). Batchelor and Bowden (1985) used $\mathrm{R}_{1}-\mathrm{R}_{2}$ of De La Roche et al. (1980) to discriminate between the different tectonic settings of granites (Fig. 13). The studied syenogranite and alkali feldspar granite intruded at syn-collision to post-orogenic stage, while the alkaline granite intruded at anorogenic stage.

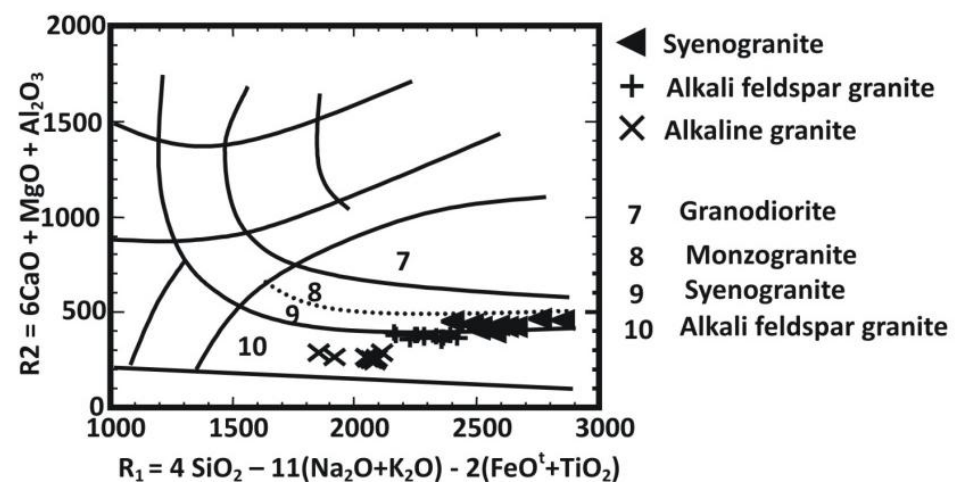

Fig. 10. $R_{1}-R_{2}$ diagram for the studied younger granites after De La Roche et al. (1980).

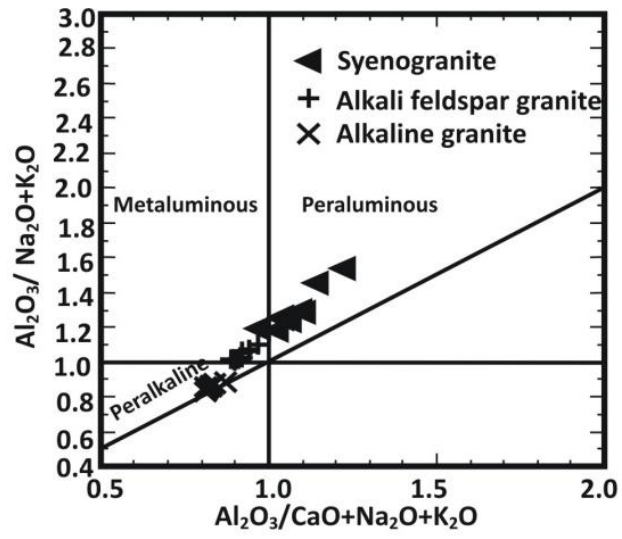

Fig. 11. Shand's index diagram for younger granites of $G$. Serbal area, after Clarke (1981). 


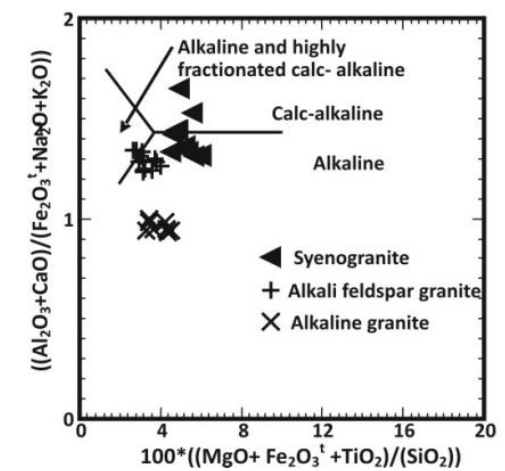

Fig. 12. Major oxides discrimination of granite for younger granites of G. Serbal area, after Sylvester (1989)

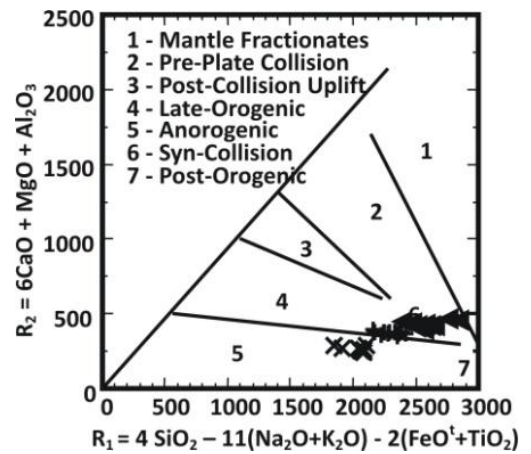

Fig. 13. De La Roch et al. (1980), multicationic variations diagram for younger granites, G. Serbal area, fields of tectonic setting after Batchelor and Bowden (1985).

According to Pearce et al. (1984), the younger granite samples lie within plate granite fields (Fig. 14). On the $\mathrm{K}_{2} \mathrm{O}-\mathrm{Rb}$ variation diagram (Fig. 15), the syenogranite samples plot between the crustal lines $\mathrm{K} / \mathrm{Rb}=250$ and $\mathrm{K} / \mathrm{Rb}=1000$. This indicates that the rocks were generated from source regions depleted in $\mathrm{Rb}$ or generated by partial melting in the lower crust or upper mantle (Gast, 1965 \& Hart and Aldrich, 1969). The alkali feldspar granite samples plot around the crustal line $\mathrm{K} / \mathrm{Rb}=250$, while the alkaline granite samples plot between the crustal lines $\mathrm{K} / \mathrm{Rb}=250$ and $\mathrm{K} / \mathrm{Rb}=100$. This indicates more differentiated and more evolved granitic liquids.

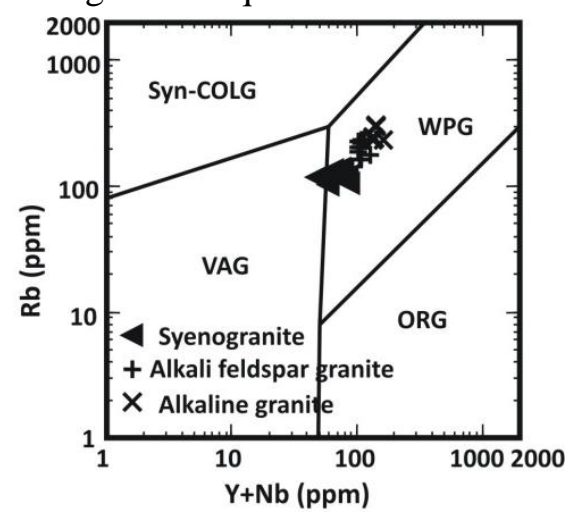

Fig. 14. Rb vs. $Y+N b$ for the studied younger granites (Pearce, et al., 1984)

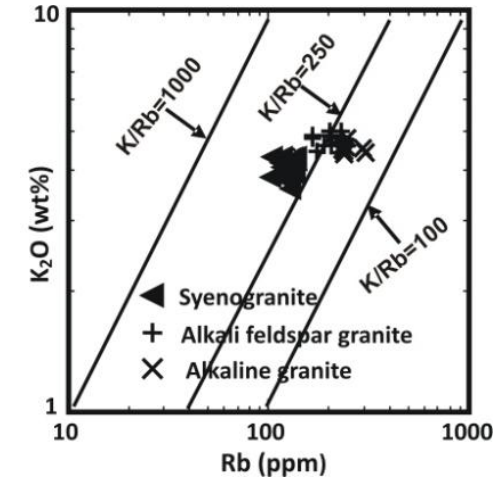

Fig. 15. $\mathrm{K}_{2} \mathrm{O}$ (wt\%) vs. $\mathrm{Rb}$ (ppm) diagram for the studied younger granites, after Shaw, 1968 
Mason (1966) used the $\mathrm{K}_{2} \mathrm{O}$-Ba variation diagram and gave the crustal average ratio of $\mathrm{K} / \mathrm{Ba}$ equal 65. Plotting of the examined samples on Fig. (16) show that the younger granites fall above the average crustal ratio. Generally, the examined samples show Ba depletion and $\mathrm{K}_{2} \mathrm{O}$ enrichment, which indicates the involvement of a second process acting with the crustal fractionation leading to depletion of Ba with differentiation (Hassan, 2001).

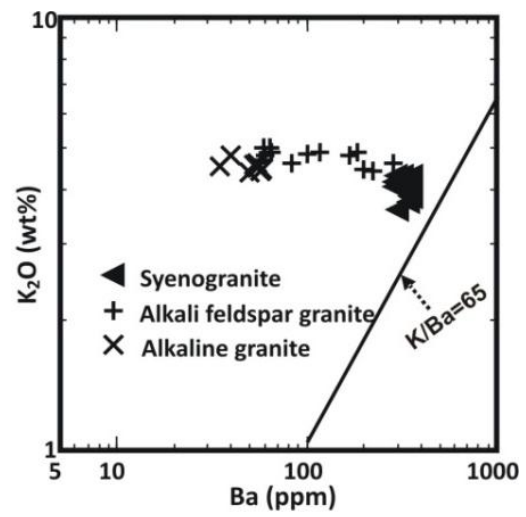

Fig. 16. $\mathrm{K}_{2} \mathrm{O}$ (wt\%) vs. $\mathrm{Ba}$ (ppm) diagram for the studied younger granites, after Mason, 1966

A plot of $\mathrm{Fe}$ number $\left(\mathrm{FeO}^{\mathrm{t}} / \mathrm{FeO}^{\mathrm{t}}+\mathrm{MgO}\right)$ versus $\mathrm{SiO}_{2}$ (Fig. 17) after Dewitt (1989) for the studied younger granites. The figure shows the syenogranite and alkali feldspar granite of $\mathrm{G}$. Serbal classified as $\mathrm{Mg}$ rich to very $\mathrm{Mg}$ rich, while the alkaline granite classified as very Fe-rich except one sample lie in Fe-rich.

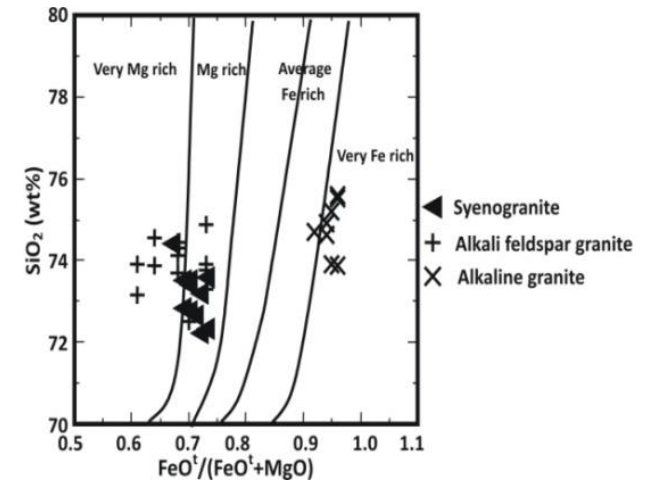

Fig. 17. $\mathrm{SiO}_{2}$ vs. $\mathrm{FeO}^{t} /\left(\mathrm{FeO}^{t}+\mathrm{MgO}\right)$ diagram for the studied younger granites. Fields after Dewitt, 1989

On plotting $\mathrm{Rb}$ versus $\mathrm{K} / \mathrm{Rb}$ (Fig. 18) for the studied younger granites. The figure shows $\mathrm{Rb}$ tends to be enriched relative to $\mathrm{K}$ in the strongly differentiated granites. $\mathrm{K} / \mathrm{Rb}$ ratios in igneous rocks result from upper mantle materials whose ratios range from 700 to 1500 (Heier, 1973). In the present study, the $\mathrm{K} / \mathrm{Rb}$ ratio of syenogranite ranges from 231 to 340 with average 277.24 . The average $\mathrm{K} / \mathrm{Rb}$ ratio of alkali feldspar granite and alkaline granite is 196 and 149 respectively. This can be attributed to the significant contribution of sialic crustal material. The strong negative relationship between $\mathrm{K} / \mathrm{Rb}$ and $\mathrm{Rb}$ in the studied granites suggests a high degree of fractionation and origin from the same magma (Ekwere, 1985).

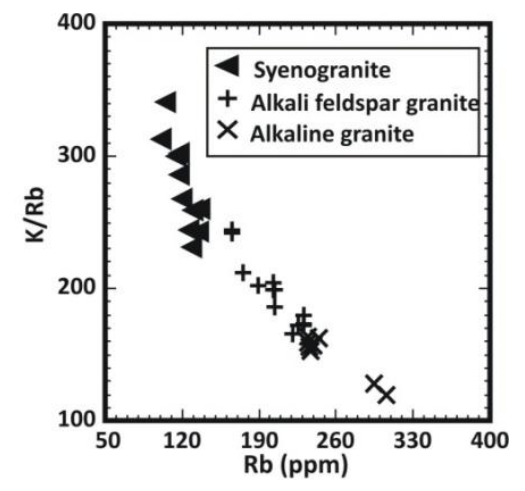

Fig. 18. $K / R b$ vs. Rb diagram for the studied younger granites

The ratio of $\mathrm{Ba} / \mathrm{Rb}$ decreases with magmatic differentiation due to crystallization of the feldspar (Fig. 19). The average crustal ratio of $\mathrm{Ba} / \mathrm{Rb}$ for granites, as given by Chapman and Hall (1997), is less 
than 4.1. In the studied syenogranite $\mathrm{Ba} / \mathrm{Rb}$ ranges between 2.23 and 3.53 with an average 2.73 , while in the alkali feldspar granite ranges between 0.25 and 1.51 with an average 0.65 . The $\mathrm{Ba} / \mathrm{Rb}$ ratio in the studied alkaline granite range from 0.09 to 0.25 with an average 0.19 . From the above data the studied younger granites were derived from crustal material. The very narrow range of $\mathrm{Ba} / \mathrm{Rb}$ ratio suggests a common magma source, while the low ratio suggests a high degree of fractionation and relative enrichment in $\mathrm{Rb}$ in comparison to $\mathrm{Ba}$ in the source magma.

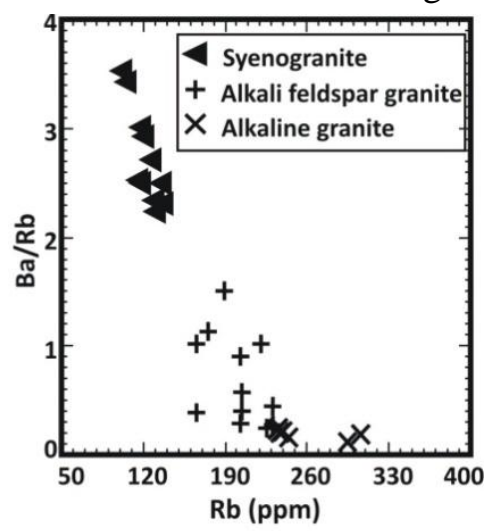

Fig. 19. $B a / R b$ vs. Rb diagram for the studied younger granites

$\mathrm{The} \mathrm{Rb} / \mathrm{Sr}$ ratio increases with magmatic differentiation (Fig. 20) due to $\mathrm{Sr}$ depletion in liquid magmas as a result of crystallization of feldspar, while $\mathrm{Rb}$ is enriched in the liquid phase. Hassan and Hashad (1990) suggested that most younger granites have $\mathrm{Rb} / \mathrm{Sr}$ more than 0.703 . The $\mathrm{Rb} / \mathrm{Sr}$ ratio in the studied syenogranite ranges from 1.05 to 2.45 with an average 1.42 . This low ratio has been interpreted by most workers to be a dervation from not much older primitive crust or contamination between mantle source and sialic crust (Dostal and Chatterjee, 2000). The average $\mathrm{Rb} / \mathrm{Sr}$ ratio in the studied alkali feldspar granite and alkaline granite are 7.72 and 33.51 respectively. On plotting $\mathrm{Zr} / \mathrm{Sr}$ versus $\mathrm{Sr}$ (Fig. 21) indicating the ratio increased with magmatic differentiation. Hall and Walsh (1969) suggested that the fertile granite is characterized by a high $\mathrm{Zr} / \mathrm{Sr}$ ratio more than 1.65 . This concept is in complete harmony with the geochemical data of the studied younger granites.

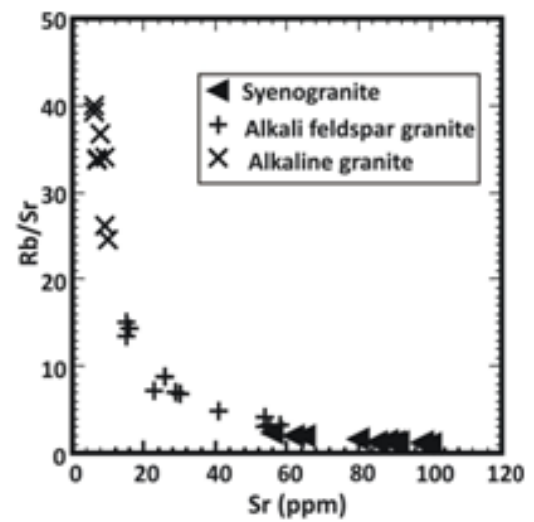

Fig. 20. $R b / S r$ vs. Sr diagram for the studied younger granites

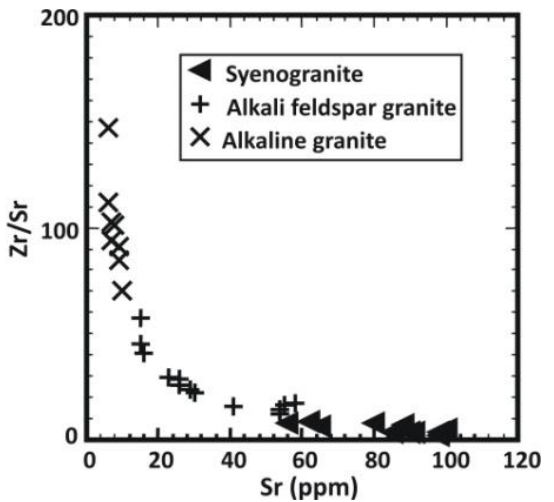

Fig. 21. $\mathrm{Zr} / \mathrm{Sr}$ vs. Sr diagram for the studied younger granites 
Contribution to the Geological, Geochemical and Mineralogical Studies of Gabal Serbal Granitic Rocks, southwestern Sinai, Egypt

Eby (1992) suggested that the $\mathrm{Y} / \mathrm{Nb}$ ratio can be distinguished among A-type granite with the mantle $(\mathrm{Y} / \mathrm{Nb}<1.2)$ or crustal $(\mathrm{Y} / \mathrm{Nb}>1.2)$ origin. The studied younger granites have $\mathrm{Y} / \mathrm{Nb}>1.2$, so values imply that the A-type is formed by fractional crystallization (Fig. 22) and partial melting (Fig. 23) of the crustal igneous rock. According to Whalen et al. (1987), the studied alkali feldspar granite and alkaline granite belong to A-type granites (Fig. 24).

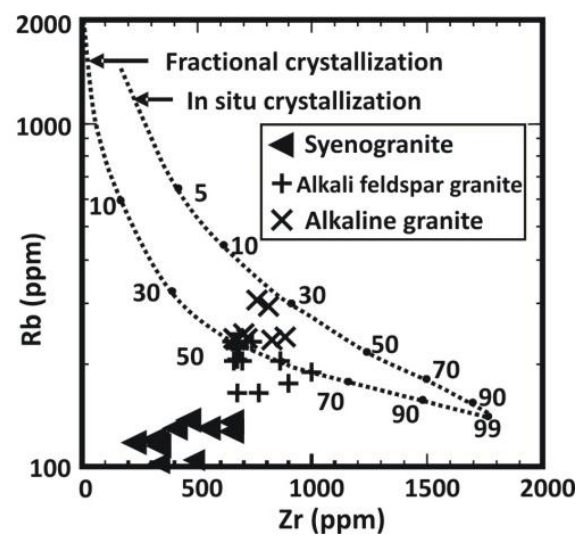

Fig. 22. $R b$ vs. Zr variation diagram compared with fractional crystallization and in situ crystallization models for the studied younger granites, after Shannon et al. (1997).

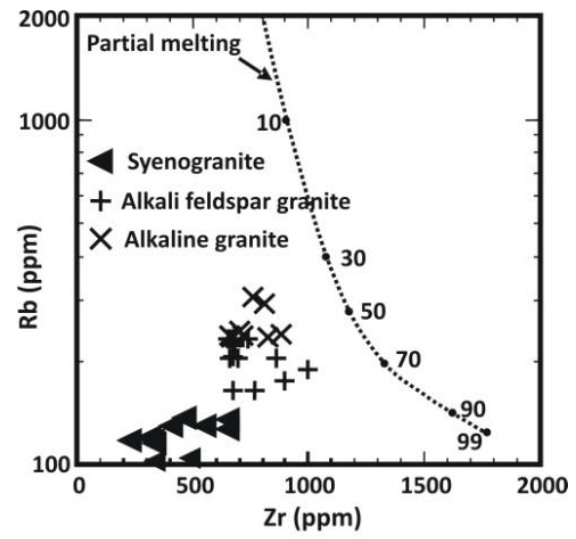

Fig. 23. Rb vs. Zr variation diagram compared with partial melting model for the studied younger granites,
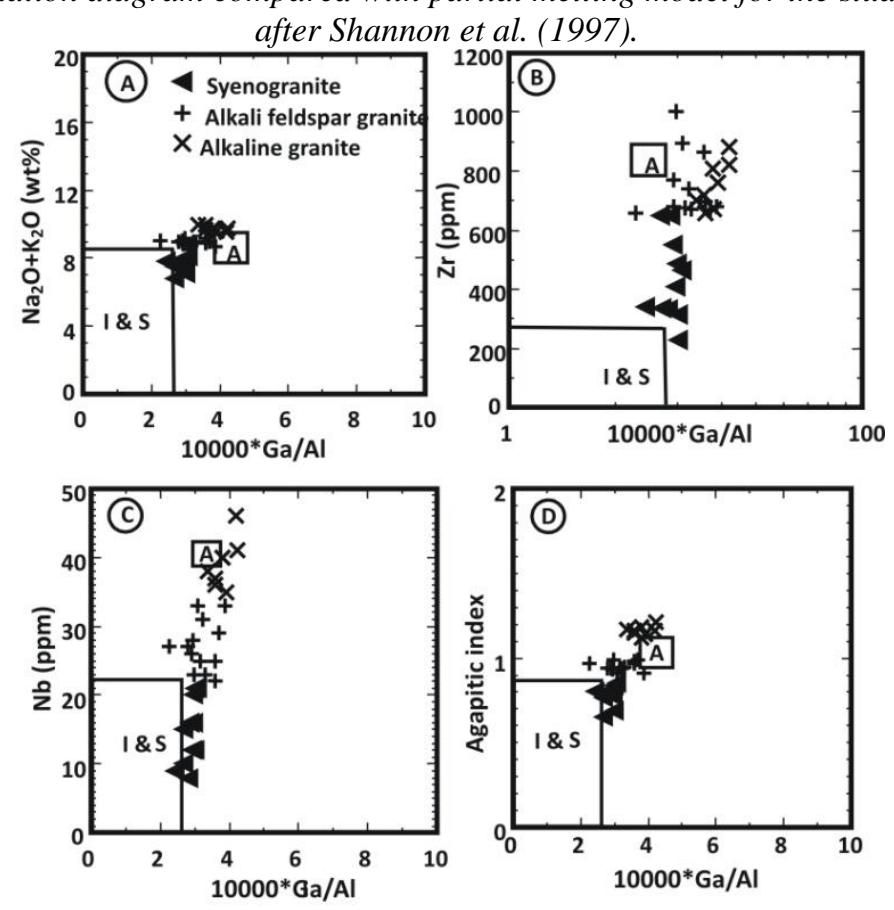

Fig. 24. $10000 * G a / A l$ vs. (A) $\mathrm{Na}_{2} \mathrm{O}+\mathrm{K}_{2} \mathrm{O}$ (B) $\mathrm{Zr}(\boldsymbol{C}) \mathrm{Nb}$ and (D) Agapitic index A-type discrimination diagram for the studied younger granites, after Whalen et al., (1987) 
The Qz-Ab-Or normative ternary diagrams (Figs. $25 \& 26$ ) reveal that the syenogranites have low water-vapour pressure (1 to $3 \mathrm{~kb}$ ) and temperature around $800^{\circ} \mathrm{C}$ suggesting a formation at moderate levels in the crust. Alkali feldspar granites have moderate water-vapour pressure $(3-5 \mathrm{~kb})$ and moderate temperature around $800^{\circ} \mathrm{C}$.

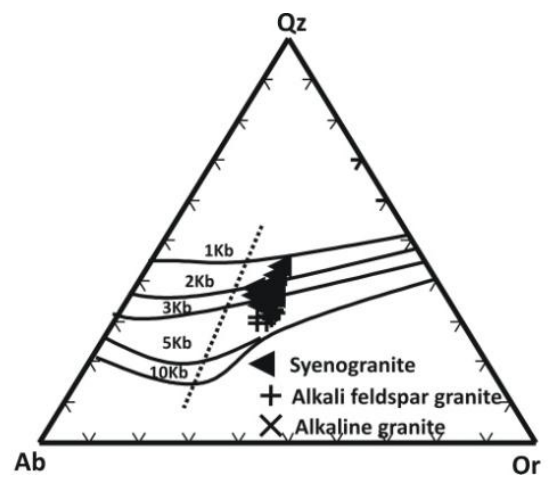

Fig. 25. $Q z$-Ab-Or diagram for the studied younger granites. The dashed line represents the minimum melting points in the granite system at different water-vapour pressure. $1,2 \& 3 \mathrm{~kb}$ after Tuttle and Bowen (1958), $5 \& 10$ $k b$ after Luth et al. (1964).

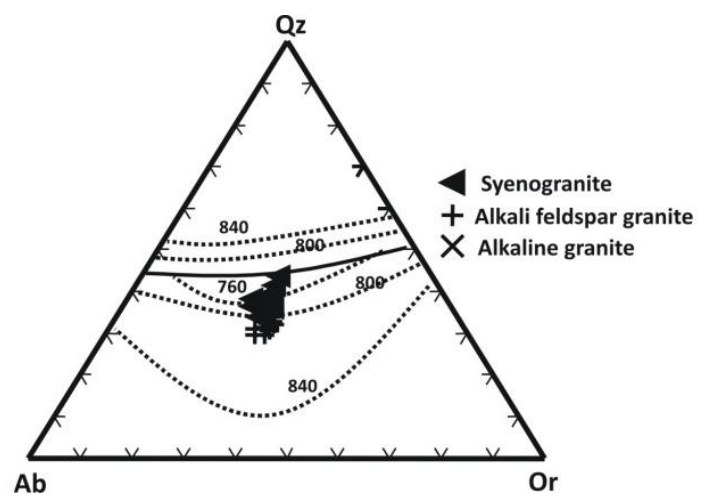

Fig. 26. Qz-Ab-Or diagram for the studied younger granites, after Luth et al., (1964)

The trace elements of the studied younger granites were normalized to the average continental crust (Hofmann, 1988) and plotted in Fig. (27). It shows enrichment in Rb, Ba (in syenogranite), Zr, Y, Nb, $\mathrm{Pb}, \mathrm{Zn}$ (in alkaline granite) and $\mathrm{Ga}$, and depletion in $\mathrm{Sr}, \mathrm{Ba}$ (in alkali feldspar granite and alkaline granite), $\mathrm{V}, \mathrm{Cr}, \mathrm{Ni}, \mathrm{Zn}$ (in syenogranite and alkali granite) and $\mathrm{Cu}$ relative to the average continental crust. The trace elements of the studied younger granites were also normalized to the average of Oceanic Ridge Granite (Fig. 28), given by Pearce et al. (1984). It shows enrichment in Rb, Ba (in syenogranite and alkali feldspar granite), $\mathrm{Zr}, \mathrm{Y}$ (alkali feldspar granite and alkaline granite), $\mathrm{Nb}, \mathrm{Pb}$, $\mathrm{Zn}$ (alkaline granite) and $\mathrm{Ga}$, and slight depletion in $\mathrm{Ba}$ (alkaline granite), $\mathrm{Y}$ (in syenogranite), $\mathrm{Zn}$ (syenogranite and alkali feldspar granite) and strong depletion in $\mathrm{Sr}, \mathrm{V}, \mathrm{Cr}, \mathrm{Ni}$ and $\mathrm{Cu}$ relative to the average Ocean Ridge Granite.

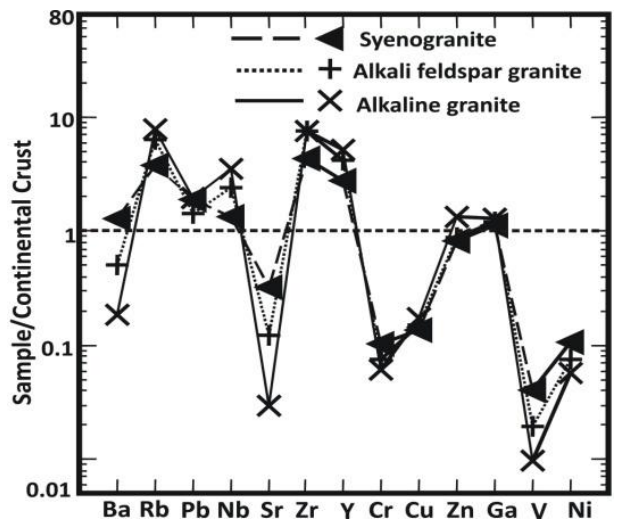

Fig. 27. Trace elements distribution pattern of the studied younger granites normalized to average continental crust (Hofmann, 1988) 
Contribution to the Geological, Geochemical and Mineralogical Studies of Gabal Serbal Granitic Rocks, southwestern Sinai, Egypt

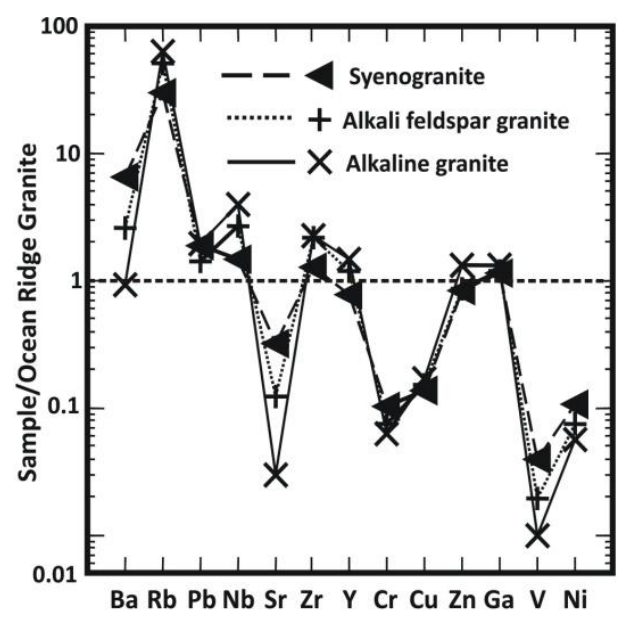

Fig. 28. Trace elements distribution pattern of the studied younger granites normalized to average of Ocean Ridge Granite (Pearce et al., 1984).

The enrichment and depletion of the compatible elements in the examined granites are related to assimilation effects of either crustal materials or oceanic matter and ruled out the effect of fractionation being responsible for the generation of granites.

\subsubsection{Geochemistry of Altered Rocks}

The study syenogranite at Wadis Abura and Geba had been suffered from alteration process along fractures. The alteration products appear in the presence of hematite, calcite and desilicification recording high radioactive measurments. Their chemical analyses are given in Table (7). The alteration in syenogranite along faults and / or fractures are deduced by geochemical studies.

Table7. Chemical analyses of altered syenogranite of G. Serbal area, SW Sinai, Egypt

\begin{tabular}{|c|c|c|c|c|c|c|c|}
\hline Oxides & AB1 & AB2 & AB3 & \multicolumn{4}{|c|}{ Trace Elements (ppm) } \\
\hline $\mathrm{SiO}_{2}$ & 63.62 & 63.80 & 62.70 & & AB1 & AB2 & AB3 \\
\hline $\mathrm{TiO}_{2}$ & 0.61 & 0.65 & 0.50 & $\mathrm{Cr}$ & 17 & 15 & 19 \\
\hline $\mathrm{Al}_{2} \mathrm{O}_{3}$ & 10.26 & 11.01 & 12.30 & $\mathbf{N i}$ & 10 & 10 & 11 \\
\hline $\mathrm{Fe}_{2} \mathrm{O}_{3}$ & 8.45 & 9.02 & 8.10 & $\mathbf{C u}$ & 11 & 12 & 10 \\
\hline $\mathrm{FeO}$ & 0.12 & 0.18 & 0.20 & $\mathbf{Z n}$ & 43 & 45 & 40 \\
\hline MgO & 1.0 & 1.10 & 1.20 & $\mathbf{Z r}$ & 443 & 460 & 420 \\
\hline $\mathrm{CaO}$ & 1.41 & 1.30 & 1.50 & $\mathbf{R b}$ & 105 & 115 & 95 \\
\hline $\mathrm{Na}_{2} \mathrm{O}$ & 6.88 & 5.50 & 5.90 & $\mathbf{Y}$ & 62 & 69 & 55 \\
\hline $\mathbf{K}_{2} \mathbf{O}$ & 3.35 & 3.40 & 3.20 & Ba & 782 & 762 & 798 \\
\hline $\mathrm{P}_{2} \mathrm{O}_{5}$ & 0.13 & 0.14 & 0.15 & $\mathbf{P b}$ & 21 & 20 & 21 \\
\hline L.O.I & 3.99 & 3.90 & 3.85 & $\mathrm{Sr}$ & 192 & 180 & 205 \\
\hline Total & 99.82 & 100.0 & 99.60 & Ga & 19 & 10 & 12 \\
\hline \multicolumn{4}{|c|}{ CIPW Normative Values } & $\mathbf{V}$ & 25 & 22 & 20 \\
\hline $\mathbf{Q z}$ & 33.06 & 33.95 & 33.69 & $\mathbf{N b}$ & 2 & 2 & 2 \\
\hline Or & 20.68 & 20.97 & 19.77 & & & & \\
\hline Ac & 25.46 & 27.15 & 24.43 & & & & \\
\hline Ns & 7.40 & 4.11 & 5.68 & & & & \\
\hline Di (wo) & 2.72 & 2.45 & 2.86 & & & & \\
\hline Di (en) & 2.19 & 1.90 & 2.28 & & & & \\
\hline Di (fs) & 0.19 & 0.27 & 0.25 & & & & \\
\hline Hy (en) & 0.41 & 0.49 & 0.86 & & & & \\
\hline Hy (fs) & 0.04 & 0.07 & 0.09 & & & & \\
\hline Ap & 0.30 & 0.32 & 0.34 & & & & \\
\hline
\end{tabular}

They are accompanied by increasing $\mathrm{Na}_{2} \mathrm{O}, \mathrm{CaO}, \mathrm{Fe}_{2} \mathrm{O}_{3}{ }^{\mathrm{t}}, \mathrm{TiO}_{2}, \mathrm{MgO}, \mathrm{LOI}, \mathrm{Ba}, \mathrm{Pb}, \mathrm{Sr}, \mathrm{Y}, \mathrm{Cu}, \mathrm{Zr}, \mathrm{V}$ and depletion in $\mathrm{SiO}_{2}, \mathrm{Al}_{2} \mathrm{O}_{3}, \mathrm{~K}_{2} \mathrm{O}, \mathrm{P}_{2} \mathrm{O}_{5}, \mathrm{Rb}, \mathrm{Nb}, \mathrm{Cr}, \mathrm{Ni}, \mathrm{Zn}$ and $\mathrm{Ga}$ (Figs. 29a and b). Plotting the altered syenogranite samples on the $\mathrm{Na} \%-\mathrm{K} \%$ diagram after Cuney et al., 1989 (Fig. 30) indicates addation of $\mathrm{Na}$ (Na- mteasomatism). According to the normative Qz-Ab-Or compositions, the altered samples colud be classified as greisen as shown in Fig. (31), after Stemprok (1979). 
Contribution to the Geological, Geochemical and Mineralogical Studies of Gabal Serbal Granitic Rocks, southwestern Sinai, Egypt

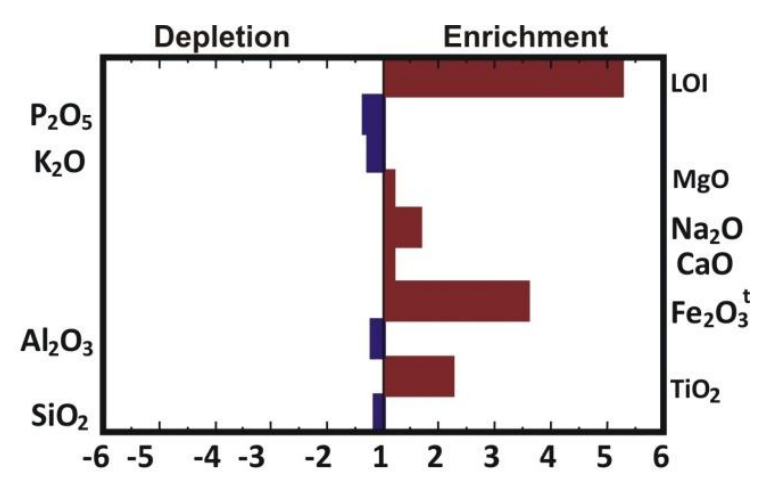

Fig. 29a. Plots of average major oxides (wt\%) of altered syenogranite compared with the average composition of fresh syenogranite

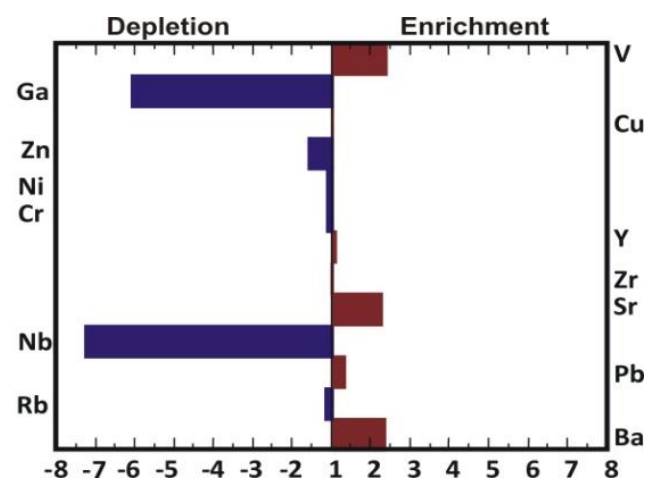

Fig. 29b. Plots of average trace elements ( $\mathrm{ppm}$ ) of altered syenogranite compared with the average composition of fresh syenogranite

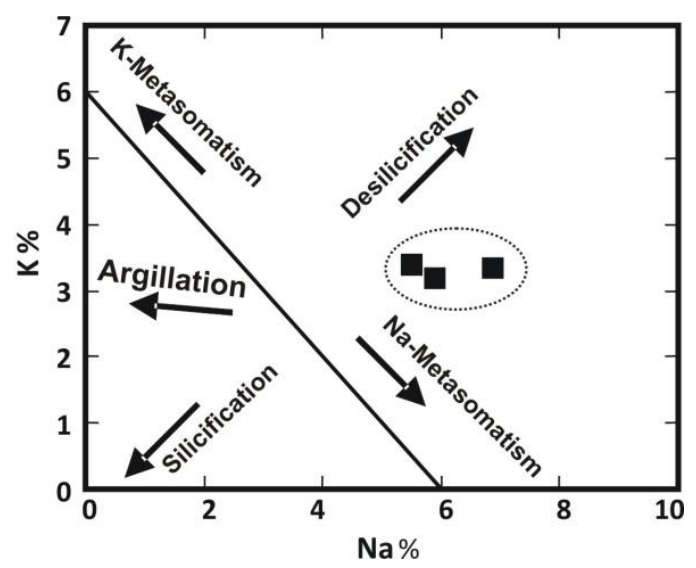

Fig. 30. $\mathrm{K} \%$ - Na \% variation diagram showing the alteration type for altered syenogranite, after Cuney et al., (1989)

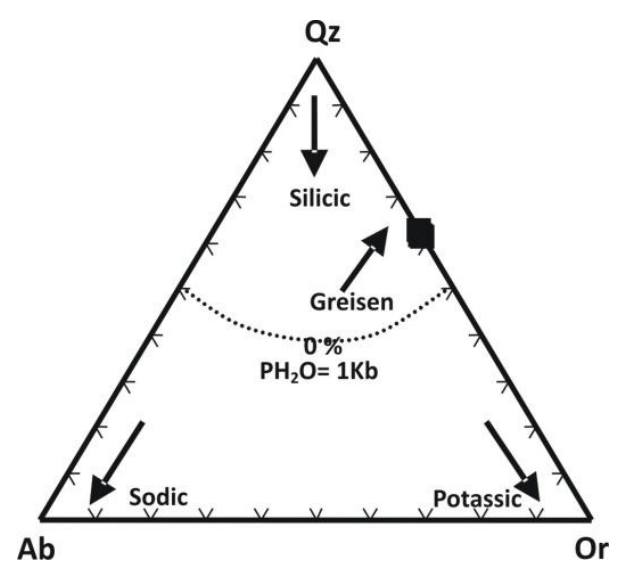

Fig. 31. Qz-Ab-Or ternary diagram of the studied altered syenogranite. The ternary minimum for $1 \mathrm{~kb} \mathrm{H}_{2} \mathrm{O}$ pressure from Tuttle and Bowen (1958). The trends of granitic alteration types are from Stemprok (1979). 
Contribution to the Geological, Geochemical and Mineralogical Studies of Gabal Serbal Granitic Rocks, southwestern Sinai, Egypt

\subsection{Spectrometric Investigation}

The average of eU, eTh and D-factor in the studied syenogranite, alkali feldspar granite and alkaline granite are $7.64 \mathrm{ppm}, 8.23 \mathrm{ppm}, 8.63 \mathrm{ppm}, 17.27 \mathrm{ppm}, 13.38 \mathrm{ppm}, 15.13 \mathrm{ppm}, 1.77,2.88$ and 2.25 respectively (Table 8 ).

Table8. Radiometric and chemical measurements of the younger granites, G. Serbal area, SW Sinai, Egypt.

\begin{tabular}{|l|l|l|l|l|l|l|l|l|l|}
\hline Rock type & & $\begin{array}{l}\text { eU } \\
(\mathbf{p p m})\end{array}$ & $\begin{array}{l}\text { eTh } \\
(\mathbf{p p m})\end{array}$ & $\begin{array}{l}\text { Ra } \\
(\mathbf{p p m})\end{array}$ & $\mathbf{K \%}$ & $\begin{array}{l}\text { U } \\
(\mathbf{p p m})\end{array}$ & $\begin{array}{l}\text { Th } \\
(\mathbf{p p m})\end{array}$ & $\begin{array}{l}\text { D- } \\
\text { factor }\end{array}$ & eTh/eU \\
\hline \multirow{3}{*}{$\begin{array}{l}\text { Syenogranite } \\
(\mathbf{n = 1 1})\end{array}$} & Min. & 5 & 9 & 1 & 2.99 & 8 & 13 & 1 & 1.71 \\
\hline \multirow{2}{*}{$\begin{array}{l}\text { Alkali feldspar granite } \\
(\mathbf{n}=\mathbf{1 3})\end{array}$} & Max. & 10 & 24 & 7 & 4.13 & 21 & 32 & 3 & 3.29 \\
\cline { 2 - 10 } & Aver. & 7.64 & 17.27 & 3.45 & 3.43 & 13.18 & 22.73 & 1.77 & 2.27 \\
\hline \multirow{2}{*}{$\begin{array}{l}\text { Alkaline granite } \\
(\mathbf{n = 8})\end{array}$} & Min. & 6 & 10 & 2 & 2.83 & 12 & 21 & 1.5 & 1.25 \\
\cline { 2 - 10 } & Max. & 10 & 18 & 5 & 5.13 & 62 & 39 & 6.2 & 2.17 \\
\cline { 2 - 10 } & Aver. & 8.23 & 13.38 & 3.46 & 3.37 & 24.77 & 30.77 & 2.88 & 1.66 \\
\cline { 2 - 10 } & Min. & 8 & 13 & 3 & 3.02 & 14 & 29 & 1.56 & 1.44 \\
\cline { 2 - 10 } & Max. & 10 & 16 & 7 & 3.46 & 25 & 38 & 2.75 & 2 \\
\hline
\end{tabular}

$n=$ number of measurements

\subsection{Radioactive Anomalies}

The anomalies in the studied area are confined to fracture cutting syenogranite at Wadis Geba and Abura. At Wadi Geba the average eU, eTh, $\mathrm{U}$ and Th contents are 170, 82, 87, $35 \mathrm{ppm}$ respectively and the dimension of anomaly is $1.0 \mathrm{~m}$ x $3.0 \mathrm{~m}$ (Fig. 32a). At Wadi Abura the average eU, eTh, U and Th are 45, 80, 82, $33 \mathrm{ppm}$ respectively and the dimension of anomaly is $2.50 \mathrm{~m}$ x $4.0 \mathrm{~m}$ (Fig. 32b). The average of D-factor equals $0.51,1.82$ indicating removal and an addition of uranium at Wadis Geba and Abura respectively (Table 9).

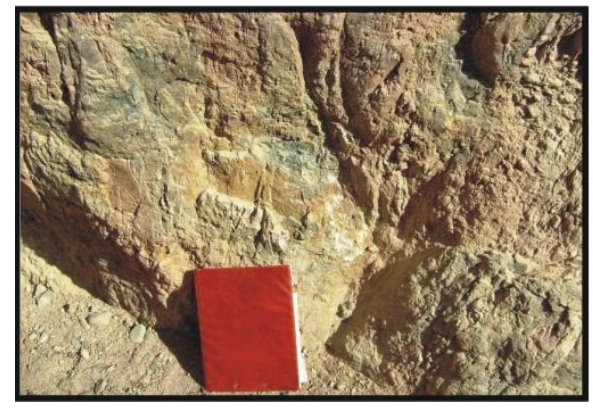

Fig. 32a. Radioactive anomaly in fracture cutting syenogranite at Wadi Geba. Looking E

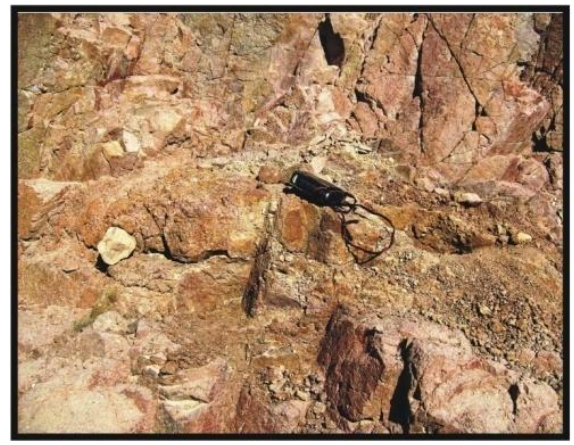

Fig. 32b. Radioactive anomaly in fracture cutting syenogranite at Wadi Abura. Looking W

Table9. Average of radiometric and chemical measurements of radioactive anomalies in G. Serbal area, SW Sinai, Egypt

\begin{tabular}{|c|c|c|c|c|c|c|c|c|}
\hline $\begin{array}{c}\text { Location of } \\
\text { anomaly }\end{array}$ & $\begin{array}{c}\mathbf{e U} \\
(\mathbf{p p m})\end{array}$ & $\begin{array}{c}\mathbf{e T h} \\
(\mathbf{p p m})\end{array}$ & $\begin{array}{c}\mathbf{R a} \\
(\mathbf{p p m})\end{array}$ & $\mathbf{K} \%$ & $\begin{array}{c}\mathbf{U} \\
(\mathbf{p p m})\end{array}$ & $\begin{array}{c}\text { Th } \\
(\mathbf{p p m})\end{array}$ & $\begin{array}{c}\text { U/eU } \\
\text { D-factor }\end{array}$ & $\mathbf{e T h / e U}$ \\
\hline Wadi Geba & 170 & 82 & 136 & 3.81 & 87 & 35 & 0.51 & 0.48 \\
\hline Wadi Abura & 45 & 80 & 32 & 2.83 & 82 & 33 & 1.82 & 1.78 \\
\hline
\end{tabular}


Contribution to the Geological, Geochemical and Mineralogical Studies of Gabal Serbal Granitic Rocks, southwestern Sinai, Egypt

\subsection{Mineralogical Investigation}

The identified minerals are classified according to its anion groups either it is radioactive or nonradioactive as follows:

\subsubsection{Silicate Minerals}

Uranophane ( $\left.\mathrm{Ca}\left(\mathrm{UO}_{2}\right) \mathrm{Si}_{3} \mathbf{O}_{8} . \mathbf{2 H}_{2} \mathrm{O}\right)$ occurs as hair- like radiate crystals of pale yellow to yellowish in colour disseminated and as micro-fracture filling as patches. It is confirmed by XRD-techniques (Fig. 33a) and by SEM-EDX (Fig. 33b) along the granite fractures at Wadi Abura.

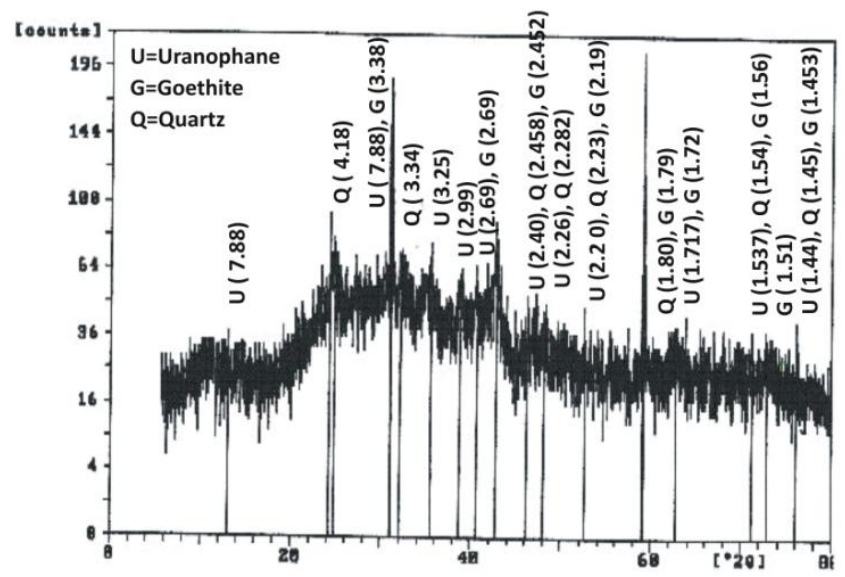

Fig. 33a. X-ray diffraction pattern of uranophane and goethite in fracture granite at Wadi Abura

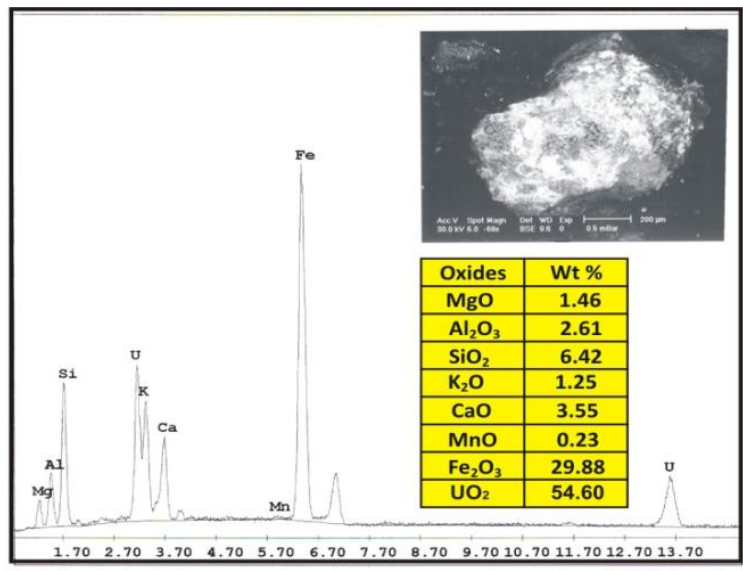

Fig. 33b. SEM-EDX analysis for uranophane in fracture cutting syenogranite at Wadi Abura

Zircon $\left(\mathrm{ZrSiO}_{4}\right)$ crystal shows different forms such as bipyramids, short prisms with brown or honey brown colour, may exist as normal or metamict. It is iso-structural with xenotime. Zirconium has important uses in the fabrication of reactor vessels and fuel element cladding in the nuclear industry. It is confirmed by SEM-EDX (Fig. 34) from the sample of fracture cutting syenogranite at Wadi Geba.

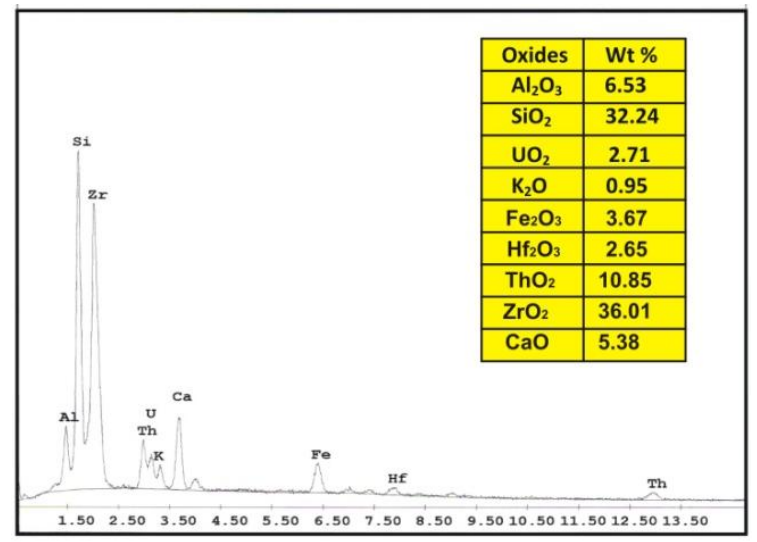

Fig. 34. ESEM-EDX analysis for zircon in fracture cutting syenogranite at Wadi Geba 


\subsubsection{Fluoride Mineral}

Fluorite $\left(\mathbf{C a F}_{2}\right)$ crystal is of cubic symmetry with octahedral, cube-octahedral or cubic habit. It occurs as colourless, light-violet, deep-violet to black in colour. It is confirmed by XRD-technique from samples of fractures cutting syenogranite at Wadi Geba (Fig. 35).

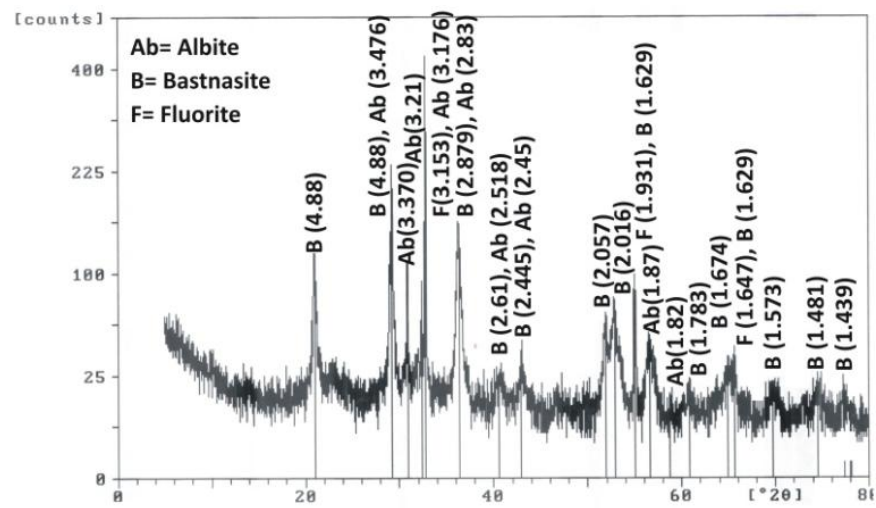

Fig. 35. X-ray diffraction pattern of bastnasite and fluorite in fracture cutting syenogranite at Wadi Geba

\subsubsection{Carbonate Mineral}

Bastnäsite ( $\mathrm{Ce}, \mathrm{La})\left(\mathrm{CO}_{3}\right) \mathrm{F}$ is one of the more widespread light rare earth bearing minerals, usually associated with allanite, cerite and fluocerite, sometimes produced as an alteration product of fluocerite. Bastnäsite plays an important role as REE resource. This mineral is separated from samples of fractures cutting syenogranite at Wadi Geba and confirmed by XRD-technique (Fig. 35).

\subsubsection{Phosphate Minerals}

Monazite (Ce, La) $\mathbf{P O}_{4}$ crystals occur as brown to reddish brown prismatic or tabular habit. Jensen (1967) concluded that the monazite structure would accept REE ions with ionic radii between those of $\mathrm{La}$ and Eu. Based on the existence of a solid-solution series between $(\mathrm{Ce}, \mathrm{La}) \mathrm{PO}_{4}$ and $\mathrm{Ca} \mathrm{Th}\left(\mathrm{PO}_{4}\right)$, the structure will accommodate ions with radii between those of $\mathrm{Ce}$ and $\mathrm{Ca}$. Monazite is confirmed by SEM-EDX (Fig. 36a) and XRD-technique (Fig. 36b) from the sample of fracture cutting syenogranite at Wadi Abura.

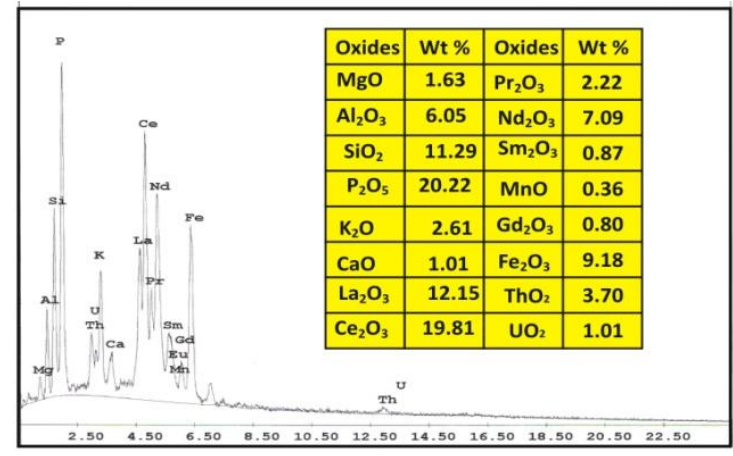

Fig. 36a. ESEM-EDX analysis for monazite in fracture cutting syenogranite at Wadi Abura.

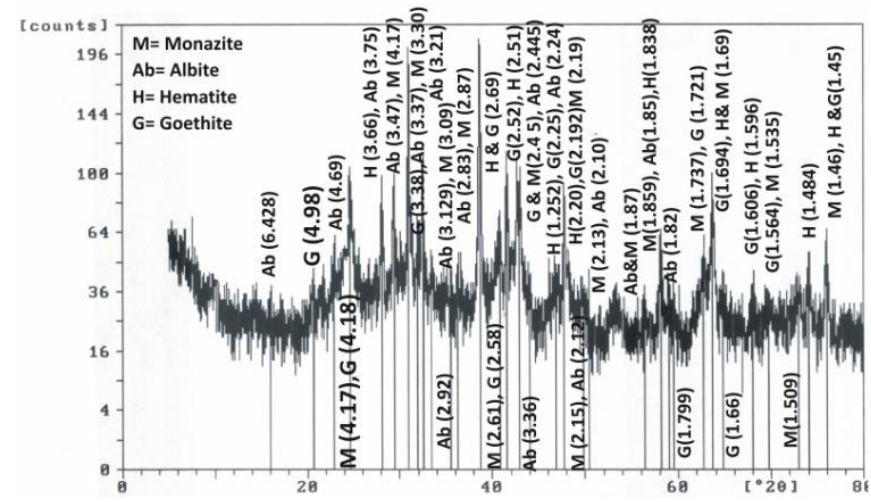

Fig. 36b. X-ray diffraction pattern of monazite, hematite and goethite in fracture cutting syenogranite at Wadi Abura. 
Contribution to the Geological, Geochemical and Mineralogical Studies of Gabal Serbal Granitic Rocks, southwestern Sinai, Egypt

\subsubsection{Hydroxide Mineral}

Goethite $\mathrm{FeO}(\mathrm{OH})$ is reddish and brownish black in colour and formed due to the disintegration of pyrite $\left(\mathrm{FeS}_{2}\right)$ (Fig. 37a). Goethite is confirmed by XRD-technique from the samples of fracture cutting syenogranite at Wadi Abura (Fig. 36b), fracture cutting syenogranite at Wadi Geba (Fig. 38).
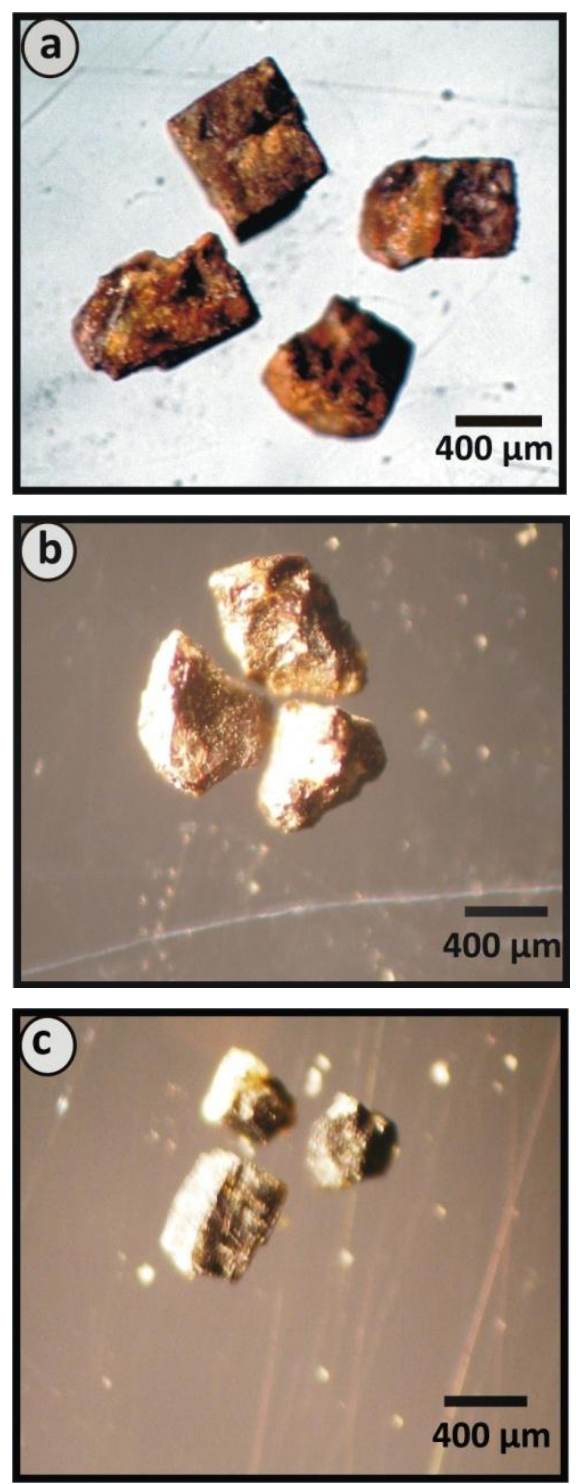

Fig. 37. Grains of some mineral species separated from the recorded anomalies, (a) Goethite., (b) Samarskite and (c) Columbite

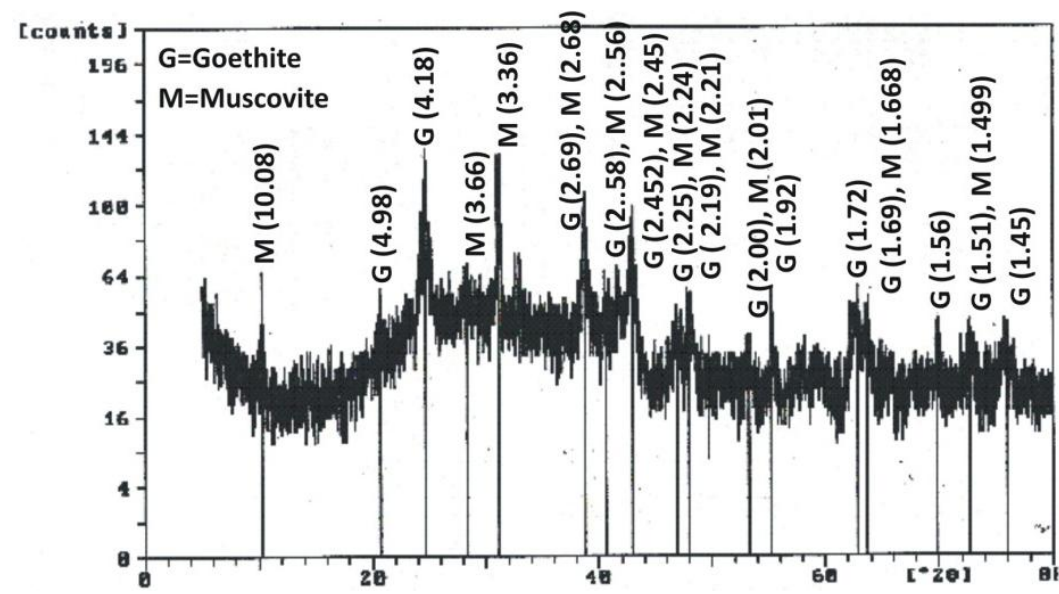

Fig. 38. X-ray diffraction pattern for goethite in fracture cutting syenogranite at Wadi Geba 


\subsubsection{Oxide Minerals}

Samarskite $(\mathbf{Y}, \mathbf{C e}, \mathbf{U}, \mathbf{F e})_{3}(\mathbf{N b}, \mathbf{T a}, \mathbf{T i})_{5} \mathbf{O}_{16}$ occurs as black prismatic or lamellar crystals with dull faces as well as irregular grains and occasionally massive (Fig. 37b). It exhibits resinous luster and conchoidal fracture Sometimes columbite is very overgrowth on the faces of samarskite. This mineral is confirmed by SEM-EDX technique (Fig. 39a) in fracture cutting syenogranite at Wadi Geba and containing $39.53 \% \mathrm{Nb}_{2} \mathrm{O}_{5}, 16.89 \% \mathrm{ThO}_{2}, 7.03 \% \mathrm{Y}_{2} \mathrm{O}_{3}$ and $6.98 \% \mathrm{UO}_{2}$. It is also confirmed by SEMEDX in fracture granite at Wadi Abura (Fig. 39b) and containing $40.50 \% \mathrm{Nb}_{2} \mathrm{O}_{5}, 13.85 \% \mathrm{ThO}_{2}, 8.5 \%$ $\mathrm{Y}_{2} \mathrm{O}_{3}$ and $3.03 \% \mathrm{UO}_{2}$.

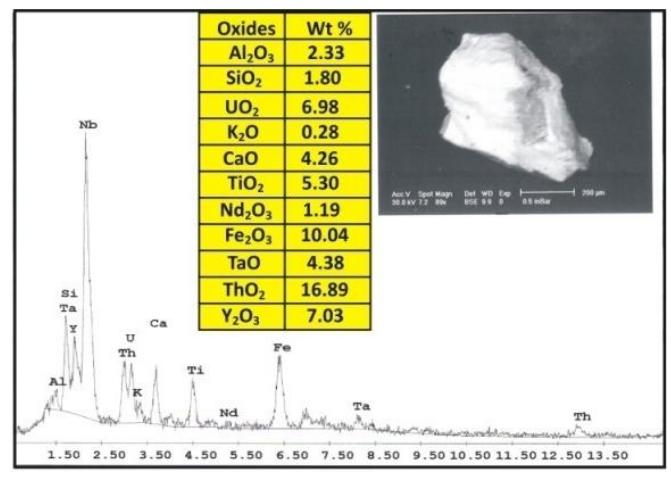

Fig. 39a. ESEM-EDX analysis for samarskite in fracture cutting syenogranite at Wadi Geba

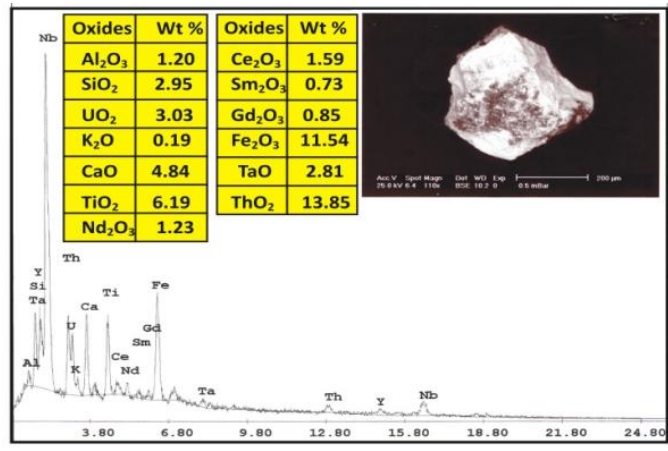

Fig. 39b. SEM-EDAX analysis for samarskite in fracture cutting syenogranite at Wadi Abura

Columbite $\left(\mathbf{N b}_{2} \mathbf{O}_{6}\right)$ Heinrich (1962) concluded that some columbite might be radioactive because of the presence of uranium and thorium in its structure, or from inclusion, veinlets, or coatings of strongly radioactive minerals. It crystallizes in the orthorhombic system and occurs as black short prismatic crystals (Fig. 37c). Columbite is confirmed by XRD-technique from the sample of fracture cutting syenogranite at Wadi Geba (Fig. 40a) and by SEM-EDX (Fig. 40b) from the sample of fracture cutting syenogranite at Wadi Abura. It contains 37.05\% $\% \mathrm{Nb}_{2} \mathrm{O}_{5}, 20.69 \% \mathrm{ThO}_{2}, 6.59 \% \mathrm{Y}_{2} \mathrm{O}_{3}$ and $5.45 \% \mathrm{UO}_{2}$.

Hematite $\left(\mathrm{Fe}_{2} \mathrm{O}_{3}\right)$ exists as granular grains with reddish brown to black in colour. It is confirmed by XRD-technique from samples of fracture cutting syenogranite at Wadi Abura (Fig. 36b), fracture cutting syenogranite at Wadi Geba (Fig. 40a).

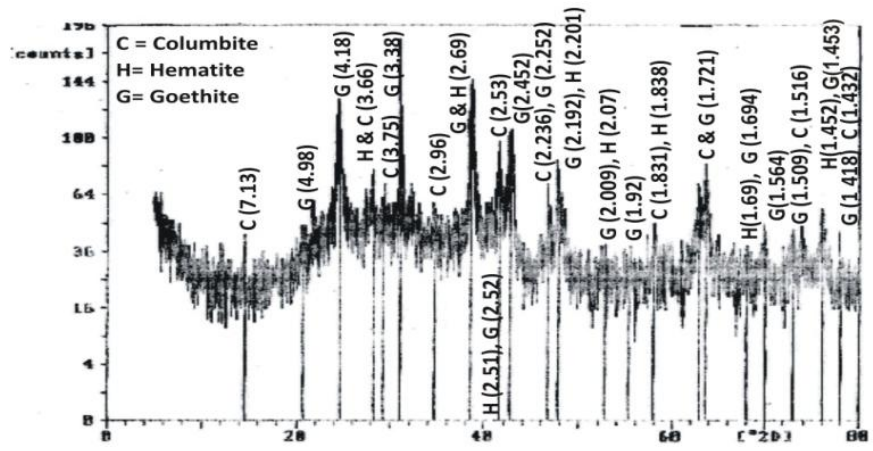

Fig. 40a. $X$-ray diffraction pattern of columbite, hematite and goethite in fracture cutting syenogranite at Wadi Geba 


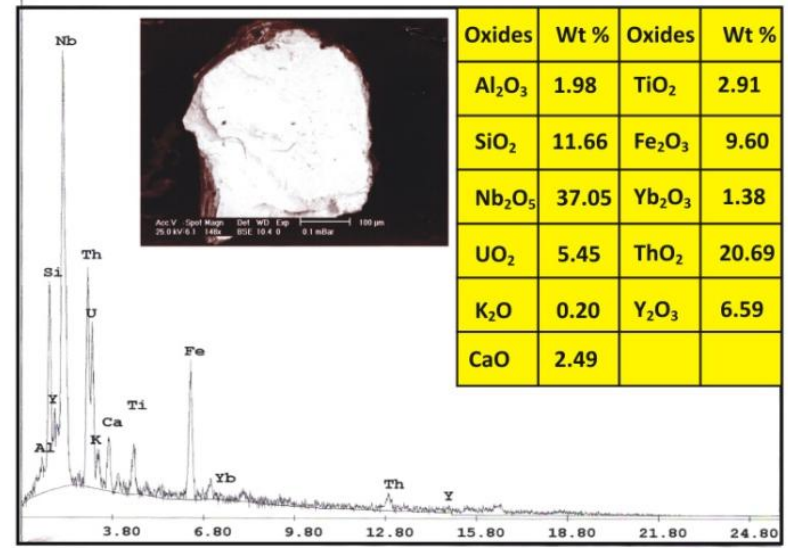

Fig. 40b. ESEM-EDX analysis for columbite in fracture cutting syenogranite at Wadi Abura

\subsection{Origin of Uranium Mineralization}

The evidences of the presence of the radioactive anomalies in the area under study can be assumed on the bases of:

- The presence of radioactive anomalies in altered younger granites fractures.

- The existence of some accessory minerals that can carry $\mathrm{U}$ and Th.

- Records of fluorite and 4-records of intensive alteration of some minerals.

From the previously mentioned notes, it can be concluded that, the magmatic role has its print and the post-magmatic changes is clear and cannot be neglected in the formation of radioactive anomalies as follows: the uranium leached from the surrounded rocks and carried by circulating solution then moves through fractures and finally absorbed by hematite from the circulating solution at Wadis Geba and Abura.

\section{CONCLUSiONS}

$>$ The study area is covered by gneisses and migmatites, metasediments-metavolcanics association, metagabbros, older granites, Dokhan volcanics, younger granite, post granite dykes and phanerozoic sedimentary rocks.

$>$ Gneisses are medium- to coarse-grained with greyish green colour and show gneissose structure. The migmatites comprise leucosome and melanosome bands. They are mostly concordant; the contact between them is sharp. Metasediments-metavolcaics association comprises hornblende schist and biotite schist intercalated with subordinate meta-andesite. Metagabbros occur as xenoliths or as roof pendants uplifted by syenogranite. Older granites are exposed between Wadi Ramuz and Wadi Wirqa and are represented by gneissose tonalite and granodiorite. Granodiorite is a hard massive rock of dark greenish grey colour and medium- to coarse-grained. Dokhan volcanics are represented by porphyritic dacite. The rocks are grey to pinkish grey in colour, jointed, crushed, faulted and dissected by sinistral and dextral slip faults. The syenogranite is medium- to coarse- grained with pink colour forming medium to high relief mountain terrains. Some fractures exhibit high alteration products represented by hematization, desilicification and record high radioactivity (Wadis; Geba and Abura). Alkali feldspar granite is medium- to coarsegrained with red colour forming high relief mountain terrains. The rocks are jointed, devoid of xenoliths and form gradational contact with syenogranite. The alkaline granite is medium- to coarse-grained with pinkish white colour forming small intrusion rounded or oval in plan. Sometimes occurs with or as offshoots in alkali feldspar granites with sharp contacts. The area is dissected by conspicuous clusters of post granite dykes forming distinct, fairly long subparallel dyke swarms. Field measurements indicate that these dykes are oriented to the NE-SW and less significantly to ENE-WSW, NNE-SSW, N-S and E-W.

$>$ Syenogranite and alkali feldspar granite have calc-alkaline to alkaline characters, emplaced in extensional environments during syn-collision to post orogenic regime and crystallized under low to moderate water-vapour pressure $(1-5 \mathrm{~Kb})$ and temperature around $\left(800^{\circ} \mathrm{C}\right)$. The alkaline 
granite has peralkaline characters, emplaced in extensional environments during anorogenic regime. The younger granites belong to A-type granite. The alteration in syenogranites along faults and / or fractures are accompanied by increasing $\mathrm{Na}_{2} \mathrm{O}, \mathrm{CaO}, \mathrm{Fe}_{2} \mathrm{O}_{3}{ }^{\mathrm{t}}, \mathrm{TiO}_{2}, \mathrm{MgO}, \mathrm{LOI}, \mathrm{Ba}$, $\mathrm{Pb}, \mathrm{Sr}, \mathrm{Y}, \mathrm{Cu}, \mathrm{Zr}, \mathrm{V}$ and depletion in $\mathrm{SiO}_{2}, \mathrm{Al}_{2} \mathrm{O}_{3}, \mathrm{~K}_{2} \mathrm{O}, \mathrm{P}_{2} \mathrm{O}_{5}, \mathrm{Rb}, \mathrm{Nb}, \mathrm{Cr}, \mathrm{Ni}, \mathrm{Zn}$ and $\mathrm{Ga}$. The alteration facies in the altered syenogranites are greisen and sodic metasomatism.

$>$ The studied syenogranite has eU contents range between 5 and $10 \mathrm{ppm}$ with an average $7.63 \mathrm{ppm}$. The eTh contents range between 9 and $24 \mathrm{ppm}$ with an average $17.27 \mathrm{ppm}$. The average of Dfactor is 1.77 , which indicates an addition of uranium. The eU contents in alkali feldspar granite range between 6 and $10 \mathrm{ppm}$ with an average $8.23 \mathrm{ppm}$ and the eTh contents range between 10 and $18 \mathrm{ppm}$ with an average $13.38 \mathrm{ppm}$. The average of D-factor is 3.0, which indicates an addition of uranium. The studied alkaline granite has eU contents range between 8 and $10 \mathrm{ppm}$ with an average $8.63 \mathrm{ppm}$. The eTh contents range between 13 and $16 \mathrm{ppm}$ with an average 15.13 $\mathrm{ppm}$. The average of D-factor is 2.24 , which indicates an addition of uranium. The anomaly is confined to fracture cutting syenogranite at Wadis Geba ( $1 \mathrm{~m} \times 3.50 \mathrm{~m}$ in dimension) and Abura ( $2.50 \mathrm{~m} \times 4.0 \mathrm{~m}$ in dimension). At Wadi Geba the average eU, eTh, $\mathrm{U}$ and Th contents are 170, 82, 87, 35 ppm respectively and at Wadi Abura the average eU, eTh, $\mathrm{U}$ and Th are 45, 80, 82, 33 $\mathrm{ppm}$ respectively. The average of D-factor equals $0.51,1.82$ indicating removal and an addition of uranium at Wadis Geba and Abura respectively.

$>$ The identified minerals from radioactive anomalies were classified according to its anion groups either it is radioactive or non -radioactive as follows: silicate minerals (uranophane and zircon), fluoride mineral (fluorite), carbonate mineral (bastnäsite), phosphate mineral (monazite), hydroxide mineral (goethite), oxide minerals (samarskite, columbite and hematite).

\section{REFERENCES}

[1] Akaad, M. K., El-Gaby, S. and Abbas, A. A. (1967): Geology and petrology of the migmatites around Feiran Oasis, Sinai, Egypt. Assu. Sci. Tech. Bull., 10, 67-87.

[2] Basta, E. Z., Kob, H. and Awadallah, M. F. (1980): Petrochemical characteristics of the Dokhan formation at the type locality, Gabal Dokhan. Eastern Desert, Egypt. Inst. App. Geol. Bull. Jeddah, 3, 121-140.

[3] Batchelor, R.A. and Bowden, P. (1985): Proterozoic interpretation of granitiod rock series using multicationic parameters. Chem. Geol., 48, 43-55.

[4] Bielski, M. (1982): Stages in the evolution of the Arabian-Nubian massif in Sinai. Ph.D. Thesis, Hebr. Univ., Jerusalem, $155 \mathrm{p}$.

[5] Chapman, C. A. and Hall, A. (1997): The nature and origin of granite. Boundary row, London. 387 P.

[6] Clarke, M.B. (1981): The mineralogy of peraluminous granites: a review, Can. Contrib. Miner. Petrol., 79, 3-17.

[7] Cuney, M., Leroy, J., Volivezo, A., Daziano, C., Gambda, B., Zarco, A. J., Morello, D., Ninci, C. and Molina, P. (1989): Metallogenesis of the uranium mineralized Achala granitic complex, Argentina: comparison with Hercynian peraluminous leucogranites of West Europe. Proc. Tech. Comm. Meetings, Vienna, TECDOC-453, I. A. E. A. Vienna, 211-232.

[8] Dewitt, E.d. (1989): Geochemistry and tectonic polarity of Early Proterozoic (1700-1750 Ma) plutonic rocks, north-central Arizona, in Jenney, J.P., and Reynolds, S.J., eds., Geologic evolution of Arizona: Arizona Geological Society Digest 17, 149-164.

[9] De La Roche, H., Leterrier, J., Grandelaude, P. and Marchal, M. (1980): A classification of volcanic and plutonic rocks using $\mathrm{R}_{1}-\mathrm{R}_{2}$ diagram and major element analyses. Its relationships with current nomenclature: Chem., Geol., 29, 183-210.

[10] Dostal, J. and Chatterjee, A. K. (2000): Contrasting behaviour of $\mathrm{Nb} / \mathrm{Ta}$ and $\mathrm{Ta} / \mathrm{Hf}$ ratios in a peraluminous granitic pluton, Nova Scotia, Canada. Chem.. Geo., 163, 207-218.

[11]Eby, G. N. (1992): Chemical subdivision of the A-type granitoids: petrogenetic and tectonic implications. Geology 20, 641-644.

[12]Ekwere, S. J. (1985): $\mathrm{Li}, \mathrm{F}$ and $\mathrm{Rb}$ contents and $\mathrm{Ba} / \mathrm{Rb}$ and $\mathrm{Rb} / \mathrm{Sr}$ ratios as indicators of post-magmatic alteration and mineralization in the granitic rocks of the Banke and Ririwai younger granite complexes, North Nigeria, Ear. Environ. Sci., 20, 89-93. 
[13]El-Gaby, S. and Ahmed, A. M. (1980): The Feiran-Solaf gneiss belt SW of Sinai, Egypt. In: Coory, P. and Tahoun, S. (eds.): Evolution and mineralization of the Arabian-Nubian Shield. Inst. Appl. Geol. Jeddah, Bull. 3 (4), 95-105.

[14]El-Gaby, S., List, F. K. and Tehrani, R. (1988): Geology, evolution and metallogenesis of the Pan-African belt in Egypt. In: S. El-Gaby \& R. O. Greiling (eds.), the Pan-African Belt of Northeast Africa and Adjacent Areas, Fried. Vieweg and Shon, Braunschweig, Wiesbaden, 17-68.

[15]El-Ramly, M. F. (1972): A new geological map for the basement rocks in the Eastern and Southwestern Desert of Egypt, Scale 1: 1000.000. Ann. Geol. Surv. Egypt, I, 1-15.

[16] El-Shazly, E. M., Abdel Hady, M. A., El-Ghawaby, M. A., El-Kassas, I. A. and El-Shazly, M. M. (1974): Geology of Sinai Peninsula from ERTS-1 Satellite Images Sensing Research Project, Academy of Scientific Research and Technology, Cairo, Egypt, 20 p.

[17] Gast, P. W. (1965): Terrestrial ratio of potassium to rubidium and the composition of the Earth's mantle. Science, 147, 858-860.

[18] Hall, A. and Walsh, J. N. (1969): Rapid method for the determination of fluorinein silicate rocks and minerals. Anal. Chem. Acta, 45, 341-342.

[19] Hart, S. R. and Aldrich, L. T. (1969): Fractionation of potassium/rubidium by amphiboles: implications regarding mantle composition. Science, 155, 325-327.

[20] Hassan, I. H. (2001): Geology, geochemistry and potentiality of radioactive mineralizations at Um Safi area, central Eastern Desert, Egypt. Ph. D. Thesis, Ain Shams Univ., Cairo, Egypt, 288 p.

[21] Hassan, M. A. and Hashad, A. A. (1990): Precambrian of Egypt. 201-245 In: Said, R. (ed.): The Geology of Egypt. Balkena, Rotterdam, 722 p.

[22] Heier, K. S. (1973): Geochemistry of granulite facies rocks and problems of their origin, Philos. Trans. Roy. Soc., London, Series, 273, 429-442.

[23] Heinrich, E. W. (1962): Radioactive columbite: Am. Mineralogist, 47, 1363-1379.

[24] Hofmann, A. W. (1988): Chemical differentiation of the earth: The relationship between mantle, continental crust and oceanic crust. Earth Plan. Sci. Letters, 90, 297-314.

[25] Jensen, B. B. (1967): Distribution patterns of rare earth elements in cerium- rich minerals. Nor. Geol. Tidsskr., 47, 9-19.

[26] Kamar, M. S. (2011): Geology, geochemistry and radioactivity of Gabal Serbal area, southwestern Sinai, Egypt. Ph.D. Thesis, Tan. Univ., Tan., Egypt, 293p.

[27] Kusky, T. M. and El-Shafei, M. K. (1999): Superimposed folding and structural evolution of the NeoProterozoic Feiran-Solaf metamorphic belt, Southern Sinai Peninsula, Egypt. Inter. Cooper bilateral Semin, 32, 135-140.

[28] Luth, W. C., Jams, R. H. and Tuttle, O. F. (1964): The granite system at pressure of 4 to 10 kilobars. J. Geophys. Res., 69, 759-773.

[29] Marchzenko, Z. (1986): Sepration and spectrophotometric determination of elements, Ellis Horwood, Chichester, England.

[30] Mason, B. (1966): Principles of Geochemistry. $3^{\text {rd }}$ Ed., John-Wiley \& Sons, New York, 239 p.

[31] Pearce, J. A., Harris, N.B.W. and Tindle, A.G. (1984): Trace element discrimination diagrams for the tectonic interpretation of granitic rocks. J. Petrol. 25, 956-983.

[32] Shannon, W. M., Branes, C. G. and Bickford, M. E. (1997): Grenville magmatism in west Taxas: Petrology and geochemistry of the Red Bluff granitic suites. J. Petrol., No. 10.

[33] Shaw, D. M. (1968): A review of K/Rb fractionation trends by covariance analysis. Geochim. Cosmochim. Acta, 32, 573-601.

[34] Shimron, A. E. (1980): Proterozoic island arc volcanism and sedimentation in Sinai. Precam. Res., 12, $437-$ 458.

[35] Shimron, A. E. (1988): Discussion on the age of Feiran basement rocks, Sinai: implication for the latePrecambrian crustal evolution in the northern Arabian-Nubian Shield, J. Geol. Soc., London, 145, 1033-1035.

[36] Stemprok, M. (1979): Mineralization granites and their origin. Episodes, 3, 20-24. 
Contribution to the Geological, Geochemical and Mineralogical Studies of Gabal Serbal Granitic Rocks, southwestern Sinai, Egypt

[37] Sylvester, P. (1989): Post collision alkaline granites. J. Geol. 97, 261-280

[38] Tuttle, O. F. and Bowen, N. L. (1958): Origin of granite in the light of experimental studies in the system $\mathrm{Na} \mathrm{Al} \mathrm{Si}{ }_{3} \mathrm{O}_{8}-\mathrm{K} \mathrm{Al} \mathrm{Si} \mathrm{O}_{8}-\mathrm{SiO}_{2}-\mathrm{H}_{2} \mathrm{O}$. Geol. Soc. Am. Mem., 74, 153.

[39] Twiss, R. J. and Moores, E. M. (1992): Structural geology. New York: W. H. Freeman and company. 532p.

[40] Whalen, J. B., Currie, K. I. and Chappell, B. W. (1987): A-type granites: geochemical characteristics, discrimination and petrogenesis. Contrib. Mineral. Petrol. 95, 407-419.

Citation: Kamar, M. S., et.al (2021). "Contribution to the Geological, Geochemical and Mineralogical Studies of Gabal Serbal Granitic Rocks, southwestern Sinai, Egypt”, International Journal of Mining Science (IJMS), 7(1), pp.29-52. DOI: https http://doi.org/10.20431/2454-9460.0701004

Copyright: (C) 2021 Authors, This is an open-access article distributed under the terms of the Creative Commons Attribution License, which permits unrestricted use, distribution, and reproduction in any medium, provided the original author and source are credited. 